LEBRETON FLATS: REDEVELOPING FORMER BROWNFIELD LAND IN CANADA'S

CAPITAL. A STUDY OF URBAN DESIGN QUALITIES AND BEST PRACTICES.

by

\author{
Sophia Kanavas \\ BA, University of Toronto, 2012 \\ A Major Research Paper \\ presented to Ryerson University \\ in partial fulfillment of the requirements for the degree of \\ Master of Planning \\ in \\ Urban Development
}

Toronto, Ontario, Canada, 2015

(C) Sophia Kanavas 2015 


\section{Author's Declaration for Electronic Submission of a MRP}

I hereby declare that I am the sole author of this MRP. This is a true copy of the MRP, including any required final revisions.

I authorize Ryerson University to lend this MRP to other institutions or individuals for the purpose of scholarly research

I further authorize Ryerson University to reproduce this MRP by photocopying or by other means, in total or in part, at the request of other institutions or individuals for the purpose of scholarly research.

I understand that my MRP may be made electronically available to the public. 


\title{
LEBRETON FLATS: REDEVELOPING FORMER BROWNFIELD LAND IN CANA- DA'S CAPITAL. A STUDY OF URBAN DESIGN QUALITIES AND BEST PRACTICES.
}

\author{
(C) Sophia Kanavas, 2015 \\ Master of Planning \\ in \\ Urban Development \\ Ryerson University
}

\begin{abstract}
In 2014, the National Capital Commission made a call for proposals to develop approximately 9.3 hectares of LeBreton Flats, a former brownfield in Canada's Capital. The objective is to create a new mixed-use community characterized by an institutional use to anchor the development. This report seeks to investigate what policies and urban design principles may be used to develop LeBreton Flats through a review of brownfield and urban design literature; policy analysis; and a review of case precedents for brownfield redevelopments. The recommendations provided seek to establish that good urban design for LeBreton Flats must contain elements of mixed-land uses with compact design; an institutional use of international or national significance to attract visitors and support local residents; walkable neighbourhoods with integrated public transportation; public realm dedication through parks and open space access to the waterfront; and innovative, architectural building construction with green design standards.
\end{abstract}

Key words:

Urban design; brownfield redevelopment; LeBreton Flats; National Capital Commission. 


\section{Acknowledgements:}

A special thank you to my MRP supervisor Dr. Z. Zhuang for her help, time, and guidance during this process, especially during moments when I needed direction in my writing and research. Thank you to Kevin Harper from Minto Group Ottawa for acting as my second reader, helping me refine my work, and sharing his knowledge of Ottawa and LeBreton Flats. Finally, thank you to Carleton University's MADGIC Library staff for granting me access to their Ottawa property maps.

\section{Dedication:}

This MRP is dedicated to my family and Mr. W. B for putting up with my insanity and late research nights; I could not have done it without you. It is also dedicated to those who supported me and showed me that I could do what I set my mind to even in the toughest of times. Thank you. 


\section{Table of Contents}

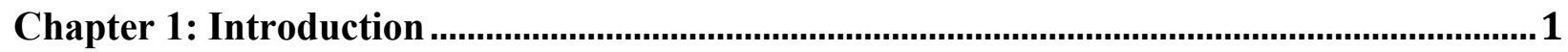

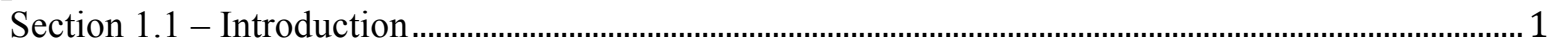

Section 1.2 - Purpose, Research Question and Methodology ………….......................................................... 3

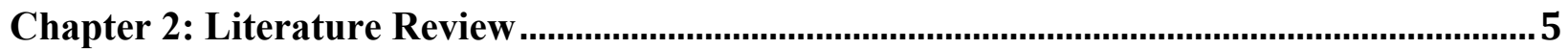

Section 2.1 - Brownfield Redevelopment Literature Review ……..................................................... 5

Section 2.2 - Urban Design Literature Review ………................................................................................. 8

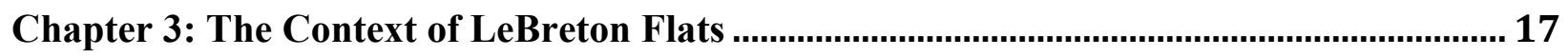

Section 3.1 - Site Location, History and Context..................................................................................... 17

Section 3.2 - Important Developments in the Flats................................................................................... 23

Chapter 4: Policy Overview ........................................................................................... 26

Section 4.1 - The Provincial Policy Statement 2014, the Planning Act and Ontario Regulations..... 26

Section 4.2 - Capital Urban Lands Master Plan and Role of the NCC ................................................. 28

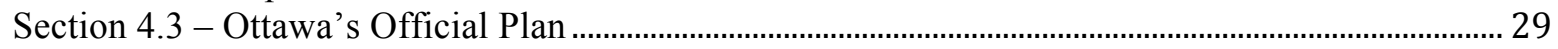

Section 4.4 - Ottawa's Brownfields Community Improvement Plan ....................................................... 30

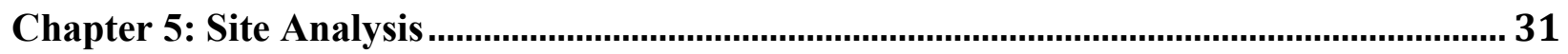

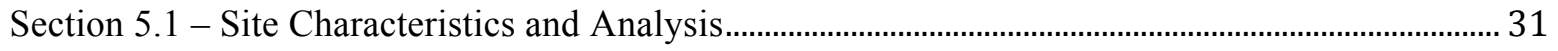

Section 5.2 - Urban Design Case Precedents for LeBreton Flats............................................................. 33

Section 5.3 - Summary of Case Precedents ........................................................................................ 43

Chapter 6: Discussion and Recommendations .........................................................................4

Recommendation 1: Compact, Mixed Land Use Development.................................................................. 44

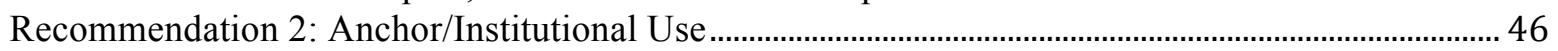

Recommendation 3: Walkable Neighbourhoods with Integrated Public Transit .................................... 47

Recommendation 4: Public Realm Dedication, Access to Open Green Space and Waterfront .......... 48

Recommendation 5: Architectural Design Excellence with Green Design and Parking ...................... 48

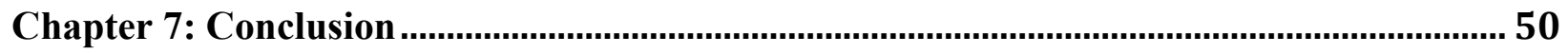

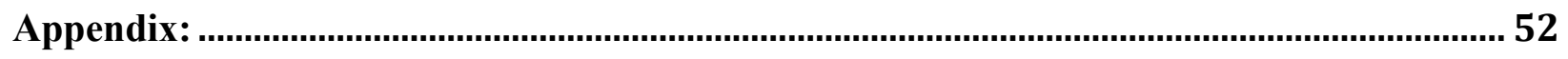

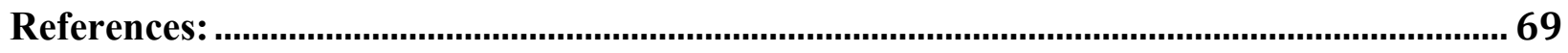




\section{List of Tables:}

Table 1: Qualities of Urban Design .....................................................................................

Table 2: Urban Design Conditions from varying sources ................................................ 14

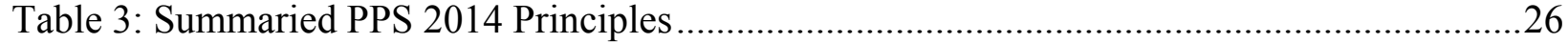

Table 4: LeBreton Flats policies as stated in the Core Area Sector Plan, 2005 ........................28 


\section{List of Figures:}

Figure 1: Figure ground map of Ottawa ................................................................................ 18

Figure 2: Built form and the developable and optional lands of LeBreton Flats ....................... 19

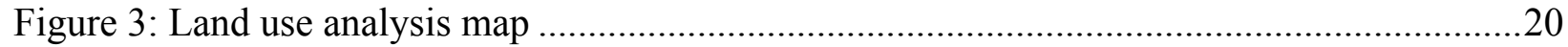

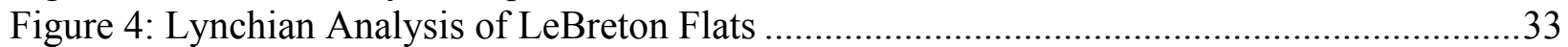

Figure 5: Conceptual land use map for LeBreton Flats........................................................52 


\section{Chapter 1: Introduction}

\section{Section 1.1 - Introduction}

Urban development in the city can often take on a shape of its own. When planning for communities or districts, planners must consult the public, conduct study areas, and plan for walkable and diverse communities. As a result, visions turn into realities with site plans and developments being created to provide housing and other institutions. Reimagining the urban core is often a difficult task fraught with many competing interests and ideas as to how to intensify downtown areas. Vacant brownfield land in downtown urban centres provides an opportunity for municipalities to reuse land that has sat desolate and undisturbed for many years long after its industrial heritage has passed. Redeveloping brownfield land is a vital part of re-envisioning downtown cores such as the West Don Lands in Toronto and LeBreton Flats in Ottawa.

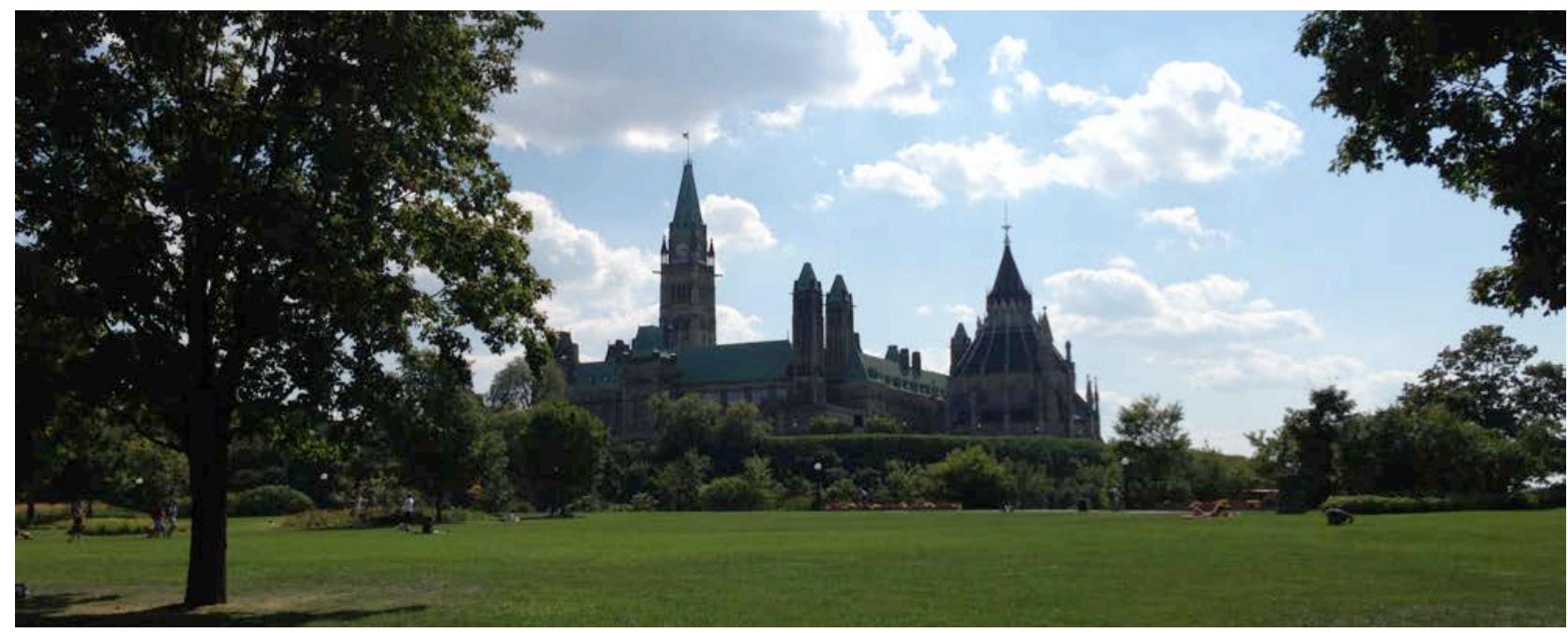

Photo 1: Sophia Kanavas (2013). Parliament Hill from Major’s Hill Park

As urban centres grow municipalities struggle to find ways to intensify and use land more efficiently. The City of Ottawa is growing with a population close to one million according to 2012 population statistics (City of Ottawa, 2015a). The City of Ottawa is responsible for planning matters, however, the National Capital Commission (NCC) is another agency that is heavily involved in planning within the nation's capital. With its monumentalist approach to capital 
planning, the NCC is a crown agency of the Federal Government of Canada whose responsibility is to preserve and ensure that Canada's capital remains a symbol of national pride while providing open spaces and cultural facilities for citizens and tourists alike (NCC, 2015a).

The NCC currently owns and is responsible for the LeBreton Flats, a formerly contaminated brownfield site that has been left vacant for decades since it was acquired in the early 1960s (NCC, 2015b). However, all roads and infrastructure servicing the area are owned and maintained by the City of Ottawa (NCC, 2014c). In 2014, the NCC put forward a call for proposals to develop approximately 9.3 hectares of LeBreton Flats with an additional 12.1 hectares that could be developed in the future (NCC, 2015c). The most interesting aspect of the site is its future development potential. For instance, the site is located adjacent the City's Confederation Line light rail transit (LRT) system, which will be completed in 2017. Given that this land is being opened for redevelopment, it is crucial to investigate urban design and policy structures that would achieve the highest and best use of the LeBreton Flats. Additionally, the NCC is adamant that the area be mixed use with an anchor institution to bring citizens and tourists into the area, as previous plans only focused on creating a large residential urban village (NCC, 2014c). According to the NCC's request for qualifications,

"[the] new objective is a creative new development scheme that has a particular emphasis on attracting a non-residential distinct anchor use, which may be a private, public/private, national or international-scale attraction or institution...[Lands for] development may be larger than what is required for some examples of key anchor use, and [the NCC] expects that the anchor must be supported by other synergistic commercial and/or recreational elements, along with multi-residential uses that would add to the richness of the mix uses and support the financial viability of the overall project." (NCC, 2014c; pp. 5).

The significance of this area to the history and future of Ottawa is acknowledged. Developing a large tract of land that has been vacant for several decades represents an opportunity for the NCC and the City of Ottawa to unlock the potential land value that has, until now, been 
locked up in the rehabilitation of previously contaminated sites. Creating a community that is mixed use, provides access to green space and recreational trails, and is dominated by an anchor institution will increase the potential to attract investment from different stakeholders.

\section{Section 1.2 - Purpose, Research Question and Methodology}

This report seeks to conceptually develop a framework of urban design best practices specifically for LeBreton Flats. Since the NCC is a crown corporation that has invested in capital planning and the public realm, proposed development should adhere to urban design principles that encourage park space and offer an institution that may be used by many. The addition of a new LRT station at LeBreton Flats further supports the creation of a mixed-use community.

Therefore this investigation asks, what policies and urban design principles may be used to develop LeBreton Flats in a way that maximizes density but also commemorates the cultural, historical, and environmental features that the NCC stands to support and promote in the nation's capital? Although this is a complex endeavour, it is meant to begin a discussion about the evaluative tools needed to transform brownfield land in a downtown area to a thriving community that adheres to planning policy, urban design standards and the character of the surrounding area. It is also important to consider what possibility an anchor institution may provide to LeBreton Flats by drawing on global examples of anchor institutions used in brownfield redevelopment.

A review of pertinent academic literature was conducted to establish a baseline for urban design practices that would apply to the site. This was also accompanied by research of municipal and federal policies regarding the site. Site visits were also undertaken in Spring, Summer, and Fall of 2014 in order to produce a site analysis, however construction in the area was a limiting factor during the investigation.

The recommendations in this report seek to establish that good urban design for LeBreton 
Flats must contain elements of mixed-land uses with compact design; an institutional use of international or national significance to attract visitors and support local residents; walkable neighbourhoods with public transportation; public realm dedication through parks and open space access to the waterfront; and innovative, architectural building construction with green design standards. 


\section{Chapter 2: Literature Review}

This chapter provides an overview to relevant literature in brownfield redevelopment and urban design, including critical works surrounding these topics.

\section{Section 2.1 - Brownfield Redevelopment Literature Review}

LeBreton Flats is characterized as brownfield land that has seen its fair share of industrial heritage over the last 200 years. According to the National Round Table on the Environment and the Economy (NRTEE), brownfields are characterized as "abandoned, vacant, derelict or underutilized commercial or industrial [properties] where past actions have resulted in actual or perceived contamination and where there is an active potential for redevelopment" (NRTEE, 2003; pp. A-3). LeBreton Flats is a known contaminated site with an archived Environmental Assessment on the Canadian Environmental Assessment Agency website stating:

"Key issues include:

- Soil contamination by metals, petroleum hydrocarbons and polynuclear aromatic hydrocarbons;

- Groundwater contamination by metals, petroleum hydrocarbons and volatile organic compounds (VOC);

- $\quad$ Risk to human health due to dermal contact, ingestion and inhalation of soil and/or groundwater contaminants;

- Impact on wildlife that used the LeBreton Flats as habitat; and

- Impact on vegetation.

Human populations potentially affected by the project (positively or negatively): In its current condition, the site poses minimal health risks for site users and adjacent properties.” (Canada Environmental Assessment Agency, 2012).

The Request for Qualifications for redevelopment by the NCC notifies potential developers that LeBreton Flats is a contaminated site, and while a portion has been remediated for the construction of the City's Confederation Line LRT, the rest of the site is in need of rehabilitation (NCC, 2014c). 
Redeveloping brownfields falls under the broader umbrella topic of sustainable urban development as it is seen as a way to conserve land and resources since brownfields are often vacant, underutilized, or derelict land (De Sousa, 2006a). According to the City of Ottawa (2010) Brownfield Redevelopment Community Improvement Plan, this type of "smart" urban development is seen as Smart Growth. This is because it efficiently uses existing services and reduces the need for new infrastructure. As many of these post-industrial sites are located in already built areas, redevelopment can improve the environment and attract investment (De Sousa, 2002). Furthermore, brownfield redevelopment reduces urban sprawl and the adverse environmental and human health effects it produces, such as automobile dependency, poor air quality, and higher rates of obesity (DePass, 2006). It also reduces development pressure on greenfield land often located in prime agricultural areas and can be used to address urban blight through infill development (City of Ottawa, 2010; NRTEE, 2003; DePass, 2006). This type of reinvestment brings economic activity to derelict and underused sites, generating employment and increased property tax revenues for municipalities. Brownfield redevelopment has the capacity to revitalize residential neighbourhoods and employment areas if given proper funding, transportation services and partnerships are developed between public and private agencies (NRTEE, 2003; Johnson, Dixson, and Tochterman, 2002). For example, Amekudzi and Fomunung (2004) examined that transportation planning can improve brownfield redevelopment as developers are more likely to develop former industrial sites if serviced with well designed, accessible transit infrastructure.

Literature has mainly focused on brownfield redevelopment being: a viable option to improve neighbourhoods through revitalization; a mechanism to increase property values and provide a local tax based enhancement; a form of sustainable urban development by reducing sprawl on greenfield land; a means of improving the environment through mitigation of contaminated 
soils and groundwater; and providing economic renewal by creating new sources of employment in underutilized areas (Hula and Bromley-Trujillo, 2010; De Sousa, 2006b; Greenberg, Lowrie, Solitare and Duncan, 2000; Heberle and Wernstedt, 2006; Leigh and Coffin, 2005).

The NRTEE (2003) provides several case studies in Canada of successful brownfield redevelopment projects that have seen significant economic, social and environmental benefits. The former brownfield site of Spencer Creek Village in Hamilton, Ontario was redeveloped into an adult lifestyle community over 12 acres of land including 40,000 square feet of commercial space. Main benefits include private sector investment, employment creation, increased property taxes, a downtown population increase, and the development of residences close to downtown services. Projects both large and small have seen positive economic and social impacts, while others such as the West Harbour Lands in Cobourg, Ontario have seen environmental benefits through increased park and open space dedication and the rehabilitation and elimination of environmental and human health hazards (NRTEE, 2003).

Moreover, some authors have written about the complexities of brownfields citing issues such as liability concerns, limited funding for remediation from government agencies, complex federal, state/provincial and local remediation regulations, uncertainty and extent of contamination, and uncertain clean-up standards as barriers to redevelopment (De Sousa, 2006b; BenDor, Metcalf, and Paich, 2011; Laitos and Abel, 2011).

Overall, the literature on brownfield redevelopment shows the benefits of reusing former contaminated or industrial sites as a means of intensifying urban areas and to combatting urban sprawl occurring on the periphery of urban centres. The literature also cites the concerns associated with redeveloping brownfield sites from a developer perspective. However, in their investigation of Michigan's brownfield policy initiative, Hula and Bromley-Trujillo (2010) found that 
the initiative opened up a viable real estate market for brownfield lands. Their most important finding was that the new market creates a private development path for sites that were deemed less contaminated than previously thought and therefore do not face as much liability and extensive clean up (Hula and Bromley-Trujillo, 2010).

\section{Section 2.2 - Urban Design Literature Review}

Urban design consists of qualities that provide spaces and places with functional, utile, and durable environments offering individuals using those spaces with emotional satisfaction and a sense of well being (Moughtin et al, 2003). More specifically, urban design concerns the physi-

cal arrangement of urban areas in regards to buildings, streets and public spaces at the city, neighbourhood, and project-specific scale to create viable, attractive and sustainable places (CIP, 2015).

Qualities of urban design may be perceptual and subjective as people experience spaces differently (Ewing et al., 2013). According to scholars such as Sternberg (2000), the study of urban design attempts to understand and explain the human experience, which is derived from the built environment regardless if space is private or public. Good design balances development and conservation, allowing the public realm to be proactive rather than reactive and transformed into an aesthetically pleasing and functional environment (Tyler and Ward, 2011). Therefore it is important to discuss place making and the identity of place in the larger context of urban design in order to provide background as to how individuals experience cities. Much research has gone into observing how people use space and the meanings that they attach to spaces within the city (Lynch, 1960; Relph, 1976). Meanwhile, place making is a direct outcome of urban design allowing practitioners to tell the narrative of the urban landscape (Childs, 2008; Sepe and Pitt, 2014). 
As stated by LaGro (2013), public spaces and places are cultural resources that allow land to be owned privately but with areas open to the public. Good urban design provides spaces with meaning, purpose and function thus encouraging the creation of place. Urban design qualities do not just encompass physical features of urban spaces, such as sidewalk width, tree canopy and traffic or pedestrian volumes, it is about the fundamental characteristics that allow people to feel comfortable in a setting and to navigate through urban areas (Ewing et al., 2013). These qualities or objectives include imageability and character, enclosure, human scale, transparency, complexity, coherence, legibility, and linkage and ease of movement (Ewing et al., 2013, CABE, 2000). Below is a description of the qualities of urban design and examples of their elements adapted from Ewing et al. (2013), Ewing and Handy (2009) and the Commission for Architecture \& the Built Environment (2000).

Table 1: Qualities of Urban Design

\begin{tabular}{|l|l|l|}
\hline Qualities of Design & Examples of Elements & Description of Quaiity \\
\hline $\begin{array}{l}\text { Imageability/Character of } \\
\text { place }\end{array}$ & Landmarks. & $\begin{array}{l}\text { The physical qualities of place that } \\
\text { give it meaning, and make it recog- } \\
\text { nizable and meaningful to individu- } \\
\text { als by capturing their attention and } \\
\text { emotions. Places that contain an } \\
\text { identity. }\end{array}$ \\
\hline Enclosure & $\begin{array}{l}\text { Unbroken building fronts } \\
\text { with equal heights. }\end{array}$ & $\begin{array}{l}\text { The visual definition of spaces de- } \\
\text { fined by buildings, walls, trees and } \\
\text { other vertical elements. Draws the } \\
\text { distinction between public and pri- } \\
\text { vate spaces and creates intimacy or } \\
\text { "outdoor rooms". }\end{array}$ \\
\hline $\begin{array}{l}\text { Human Scale } \\
\text { quality of the public realm }\end{array}$ & $\begin{array}{l}\text { Building height but can also } \\
\text { buildings with specific uses } \\
\text { refer to human walkability, } \\
\text { i.e. walkable environments } \\
\text { for people instead of cars. }\end{array}$ & $\begin{array}{l}\text { The scale of physical elements } \\
\text { (buildings and streets) that consist of } \\
\text { components of size that match and } \\
\text { relate to the proportions of human } \\
\text { form and function. }\end{array}$ \\
\hline
\end{tabular}




\begin{tabular}{|c|c|c|}
\hline & $\begin{array}{l}\text { (i.e. schools), and high tree } \\
\text { canopies. }\end{array}$ & $\begin{array}{l}\text { or public space and the human activ- } \\
\text { ity that takes place there. Also the } \\
\text { material condition of physical ele- } \\
\text { ments that makes them pervious to } \\
\text { light and air greatly influences trans- } \\
\text { parency. }\end{array}$ \\
\hline Complexity/Diversity & $\begin{array}{l}\text { Street furniture and diversity } \\
\text { of building ages and use. }\end{array}$ & $\begin{array}{l}\text { Visual richness of a place that is de- } \\
\text { termined by the physical environ- } \\
\text { ment through architecture and orna- } \\
\text { mentation, signage, diversity and } \\
\text { number of buildings and human ac- } \\
\text { tivity. A place that offers a variety } \\
\text { and choice of uses. }\end{array}$ \\
\hline Coherence & $\begin{array}{l}\text { Ordered diversity of com- } \\
\text { mon building masses, build- } \\
\text { ing setbacks, and landscap- } \\
\text { ing. }\end{array}$ & $\begin{array}{l}\text { Visual order determined by the con- } \\
\text { sistency and corresponding physical } \\
\text { environment (scale, character and } \\
\text { arrangement of physical elements } \\
\text { such as buildings, landscaping and } \\
\text { street furniture). }\end{array}$ \\
\hline $\begin{array}{l}\text { Legibility (linked to im- } \\
\text { ageability) }\end{array}$ & $\begin{array}{l}\text { Recognizable routes, land- } \\
\text { scape features, signage for } \\
\text { way finding. }\end{array}$ & $\begin{array}{l}\text { The ease of navigation in a spatial } \\
\text { structure of a place. A mental map } \\
\text { that allows people to interpret and } \\
\text { read the spatial environment of a } \\
\text { place. }\end{array}$ \\
\hline Linkage/ease of movement & $\begin{array}{l}\text { Connective transit through } \\
\text { shorter transit stops, shorter } \\
\text { blocks. }\end{array}$ & $\begin{array}{l}\text { The physical and visual connection } \\
\text { from space to space (buildings and } \\
\text { streets, buildings to building or one } \\
\text { side of a street to another). Based on } \\
\text { the ability for people to physically } \\
\text { move from one space to another; to } \\
\text { get where they need to go with ease. }\end{array}$ \\
\hline
\end{tabular}

Within urban design most literature has focused on three main principles: design at the city scale; design at the neighbourhood scale; and deign at the project level (or site specific level) (Tyler and Ward, 2011). Urban design scholars have written extensively about design at the city scale. Historically, this work is most popularly attributed to the theories and designs of the early urban design thinkers such as Daniel Burnham, Ebenezer Howard, Frederick Law Olmstead, and 
Le Corbusier. For these thinkers, their conceptual approaches to planning and urban design made significant changes in how to design spaces for the public. They also set a historical precedent of the reconceptualization of design in the mid- $20^{\text {th }}$ century which provides the basis for understanding that design and good urban form are not a static process, but rather an iterative one (Larice and MacDonald, 2007).

In The Image of the City, Kevin Lynch (1960) points to the imageability and legibility of the city to the participant and observer within urban areas. According to Lynch, the way people imagined their city had much to do with the legibility of urban space and how people read their urban landscape (Lynch, 1960; Montgomery, 1998). The ability of individuals to imagine the city in their mental mind and to create a mental map to read urban areas is central to legibility, whereas imageability consists of the qualities of place that make it memorable and distinct by capturing attention and emotion (Ewing et al., 2013). Through his research, Lynch (1960) describes five elements essential to urban design and form that describe how individuals perceive the legibility of urban spaces, these include: Paths, Edges, Districts, Nodes and Landmarks. All contain their specific functional elements within place making in the city, neighbourhood, and site-specific scales. Paths are areas along which people move such as sidewalks, walkways, transit lines, or canals. Lynch (1960) states that paths are the predominant way in which people experience urban areas, as they are observers that pass through different areas of a city. Edges are physical, linear spaces that are secondary to paths. In other words, edges consist of boundaries, which people normally do not travel along; instead, they consist of physical structures such as railways lines, walls, or shorelines. Districts are medium-to-large parts of the city in which people mentally enter and are mostly visible when they are located inside a district due to its identifiable character (Lynch, 1960; Sternberg, 2000). Nodes act as focal points where people 
enter and in which interaction with people and place is likely to occur, such as an intersection or convergence of paths. Therefore nodes are related to paths and districts as people travel along paths that might converge or enter into a core, which could be in the centre of a district. Finally, landmarks act as an external point of reference for individuals and provide a visual cue, such as architecturally innovative buildings, performing arts centres, or clock towers. Fast-forward to design in the early $21^{\text {st }}$ century, the urban armatures of the city are the main concern of the urban designer as the pattern of public activity revolves around the downtown core (Erickson, 2001). Much like Lynch's five elements, the urban armature contains basic principal components that an urban designer should be concerned with in regards to design and form of the city, including public spaces in parks, squares, and along main roads and transport arteries (Erikson, 2001). From these elements, gathering spaces would be added which include community centres, religious buildings, retail centres and leisure and recreational places. Final elements would include features that provide an identity to place, such as monuments, landmarks, and cultural institutions (Erickson, 2001).

At all three scales the key to good design is observation of people, spaces, the interaction between the two, and the transactions within space. This can be observed just by looking at cities as suggested by Allan B. Jacobs in his 1985 book of the same name. Jacobs (1985) describes the importance of observation in relation to cities. William Whyte in The Social Life of Small Urban Spaces investigated small parks and squares in New York City coming to a similar conclusion that in order to understand and design spaces for people, urban designers must first understand how that space is used. Jacobs (1985) explains that observing how space is used and analyzing urban areas can aid in understanding how it changes over time. It can reveal clues about spaces and tells the history of a place. However, Jacobs warns that not all urban clues and meanings are 
easily understood or straightforward. Therefore continuous questioning partnered with critical, conscious observation can reveal a lot of information about a neighbourhood, district or city (Jacobs, 1985). Visual observation can lead to how people perceive different landscapes in the city at different scales. This type of visual communication is important to the design of urban places as they convey information about the buildings and places in which people travel through (Jacobs, 1993). The implication of observation provides urban designers with the opportunity to create new innovative spaces within the city, neighbourhoods and small urban spaces that reflect the eight qualities of urban design outlined above.

Furthermore, Jane Jacobs (1960) describes what she observes about cities that work in particular neighbourhoods. Since urban design is about making spaces that work yet are also beautiful, Jacobs' conclusions about city life have been applicable to almost all urban settings providing several themes through her observations of city life in neighbourhoods that were diverse and thriving. In terms of design, walkability is a critical characteristic of a functional public realm. Jacob's (1960) discussion about sidewalks indicates that their physical design provide an important form of infrastructure acting as a transportation route but also serving as public space. To be successful, sidewalk environments have to make people feel safe and secure with other strangers. Therefore Jacobs proposed three main qualities that sidewalks must have: a clear demarcation of what is public and private space; 'eyes on the street' at all times from front porches or window fronts; and users have to be continuously occupying the street. These qualities are echoed by Allan B. Jacobs' (1993) work, in which he describes the essential characteristics that are required to create great streets in urban areas. Jacobs (1993) argues that great cities are comprised of great streets that contain a number of elements lending to their success within the cities. Streets are part of the overall public realm and therefore have to be conducive to peo- 
ple to walk with leisure. Great Streets, such as the Champs-Elysees in Paris, provide an environment that is safe and encourages leisurely walking. The environment of the street must be able to support transit, vehicles, and pedestrians, which can be easily accomplished by means of careful right-of-way design. Safety can be encouraged not only through the use of curbs and sidewalks as physical barriers to road traffic, but also through the use of trees arranged on the curb line to offer a pedestrian safe zone (Jacobs, 1993). This connects to enclosure and transparency by allowing people to be in an intimate place but also be able to "see and/or perceive what lies beyond the edge of a street or...public space and...the degree to which people can see or perceive human activity beyond the edge of a street or other public space” (Ewing et al., 2013; pp. 11).

Urban designers and planners have discussed at length the conditions needed in order to encourage diversity of land use, character and urban form (Jacobs, 1960; Alexander, 1979; Montgomery, 1998; Jabareen, 2006; Tyler and Ward, 2011). Below is a summarized list of Jacobs' (1960) four conditions, Montgomery's (1998) twelve physical conditions for making a city, and Jabareen's (2006) seven design concepts of sustainable urban form.

Table 2: Urban Design Conditions from varying sources

\begin{tabular}{|l|l|}
\hline & Design Theme/Condition/Concept \\
\hline Jacobs (1960) & Four Conditions: \\
& 1) Mixture of Primary Use \\
2) Small Blocks \\
3) Aged Buildings \\
4) Concentration or Density \\
(1998) & Twelve Conditions for Making a City: \\
& 1) Development Intensity \\
2) Mixed Use \\
3) Fine Grain \\
4) Adaptability \\
5) Human Scale \\
6) City Blocks and Permeability \\
7) Streets: Contact, Visibility and Horizontal Grain \\
8) Public Realm \\
9) Movement \\
10) Green Space and Water Space
\end{tabular}




\begin{tabular}{|l|l|}
\hline & 11) Landmarks, Visual Stimulation and Attention to Detail \\
\hline Jabareen & Seven design concepts of sustainable urban forms: \\
$(2006)$ & 1) Compactness \\
& 2) Sustainable transport \\
& 3) Density \\
& 4) Mixed Land Uses Diversity \\
& 5) Passive Solar Design \\
\hline
\end{tabular}

Literature has emphasized the need for mixed land use as a primary design element for creating successful urban areas. Primary land uses attract diversity by creating landmarks that attract a secondary diversity of businesses that thrive on the primary uses (Jacobs, 1960; Montgomery, 1998). Uses can include residential dwelling types that spur other uses such as entertainment, restaurants, and shopping facilities both horizontally in a city block and vertically in the same building on the same site (Montgomery, 1998). This diversity of land use can encourage a concentration of amenities and services and comes in the form of density. A dense concentration of people within a district or neighbourhood makes best use of services and amenities and keeps sidewalks safe with more 'eyes on the street' (Jacobs, 1960). It also reflects sustainability, as the ratio of people to land area is higher, thus conserving resources such as energy and materials while encouraging social interaction due to compact form (Jabareen, 2006). However, density is also contextual as one type of density may work well in one area of the city but not in another. Therefore, a mixture of building types is needed in order to provide appropriate density without overwhelming neighbourhoods and districts.

Human scale is a quality of design and a condition that manifests in compactness. Small blocks provide walkable scales that allow individuals to explore different areas of their neighbourhood and provide opportunities to take different routes (Jacobs, 1960; Montgomery, 1998). Small and short blocks discourage the isolation of pathways, which individuals can take for their 
routes. Therefore, the compactness of an environment intensifies urban areas by producing more activity in a given area and increasing a sense of grandeur or enclosure (intimacy) of a space (Montgomery, 1998; Jabareen, 2006).

The public realm consists streets, open spaces, parks, and green spaces. Whyte (1980) identified seven elements essential to successful small urban spaces: trees for shade; water; sun for light and warmth; easy access to the street to invite people into the space; food as a means of socialization; triangulation; and sitting space, in particular moveable seating. Whyte (1980) found that the most successful urban spaces contained several, if not all of these elements making them important factors in physical and social interaction in urban areas. Much similar to Whyte, Jacobs (1993) identifies that great streets offer a comfortable atmosphere, one where there is warmth and sunlight when weather is cool and shade and temperate coolness when the weather is hot. Jacobs (1993) echoes many other principles that Whyte found in his study of small urban spaces citing that "people understand and respond to comfort" (pp. 276). They willingly seek out places that provide a comfortable climate. Beyond just looking at the comfort of streets, the urban design of areas depends on streets having boundaries that communicate where edges are located, such as walls, trees, and the spacing between buildings (Jacobs, 1993). 


\section{Chapter 3: The Context of LeBreton Flats}

\section{Section 3.1 - Site Location, History and Context}

LeBreton Flats is located adjacent downtown Ottawa to the east, on the shore of the Ottawa River with two parcels available for redevelopment, the north parcel measuring 5.7 hectares, and the south parcel measuring 3.7 hectares. To the west of the developable parcel is another 12.1 hectares, which are proposed for optional development in the future. Three neighbourhoods surround the Flats: Centretown to the east, which is part of Ottawa's downtown core; West Centretown to the south; and Hintonburg/Mechanicsville to the west. The Sir John A. Macdonald Parkway borders the north parcel and Albert Street boarders the south parcel. The City's bus rapid transit route (Transitway) divides the parcels. Booth Street and Preston Street define the eastern and western boundaries of the development site respectively.

\section{Photo 2: North Parcel}

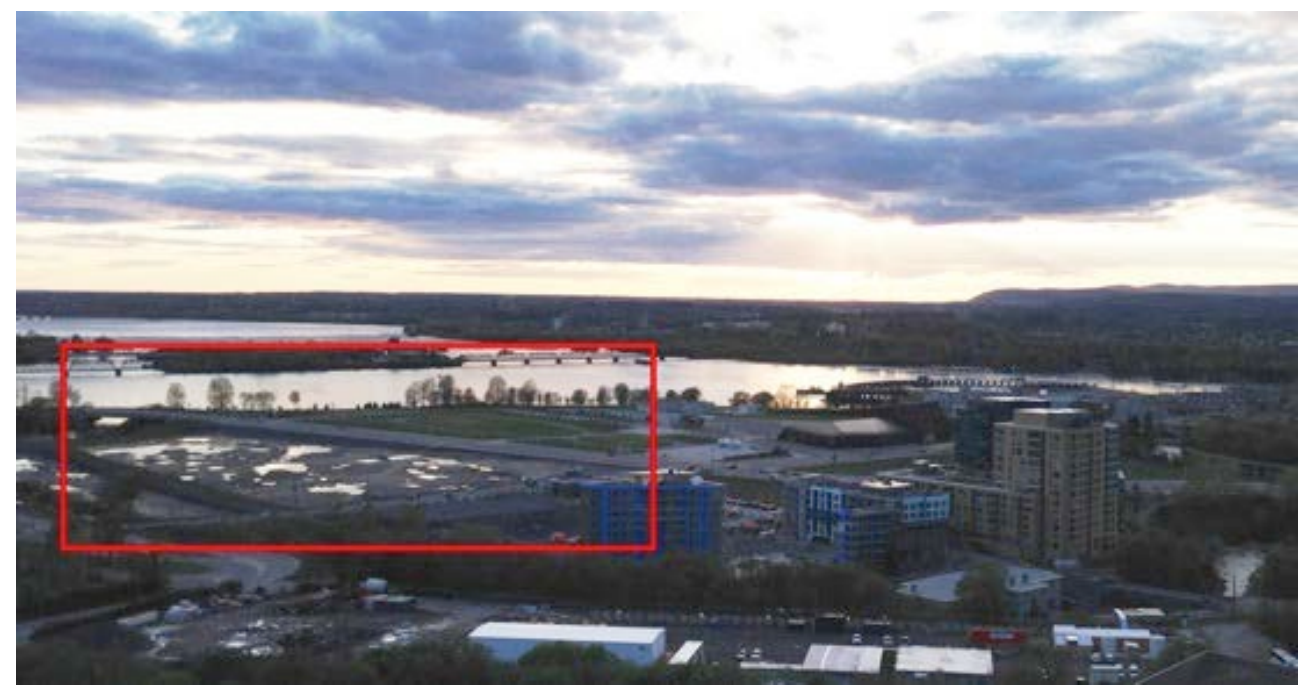


Photo 3: South Parcel

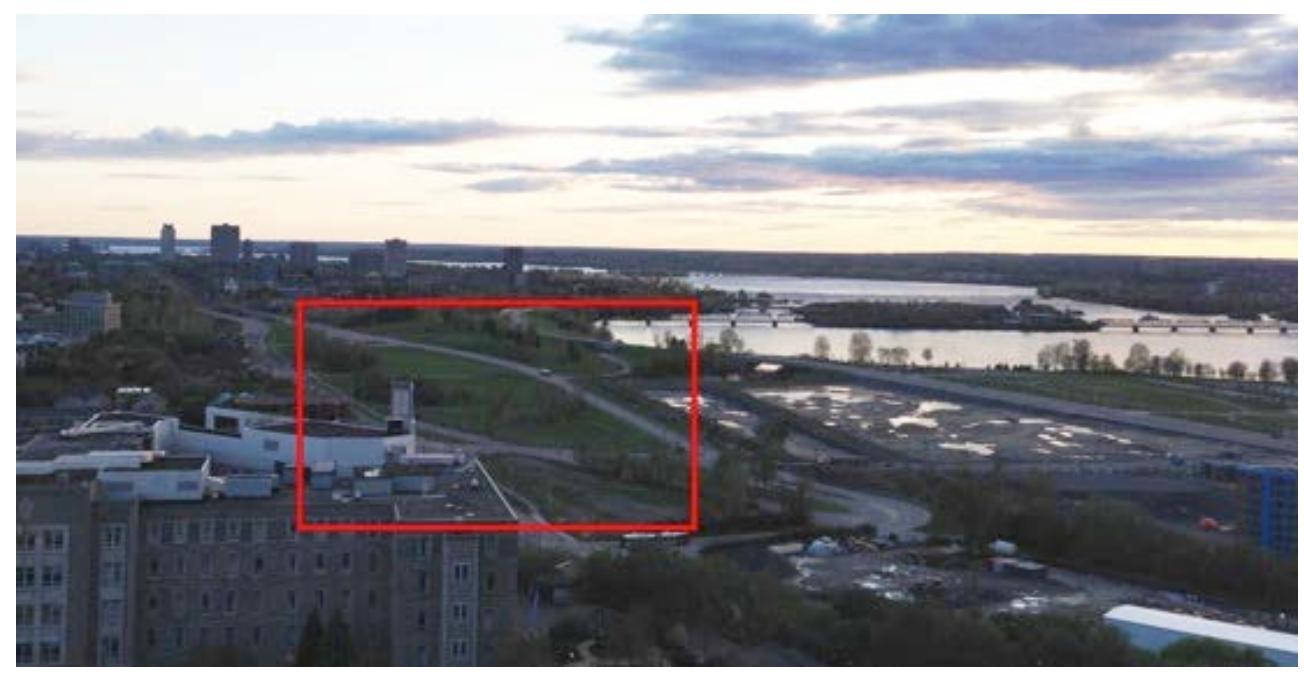

Photos by: Sophia Kanavas

Figure Ground Map of Downtown Ottawa

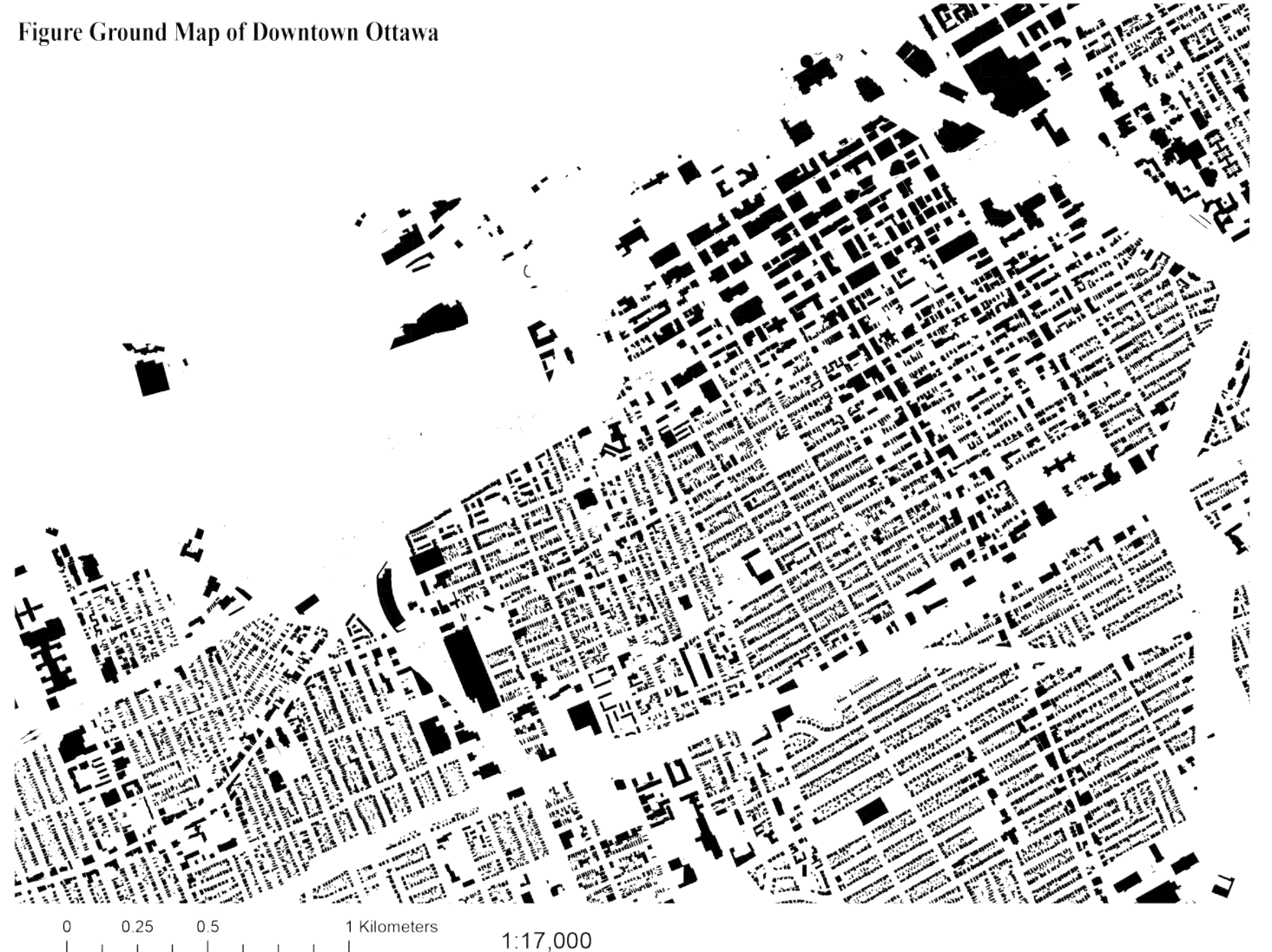

Figure 1: Figure ground map of Ottawa

*not to scale due to formatting 


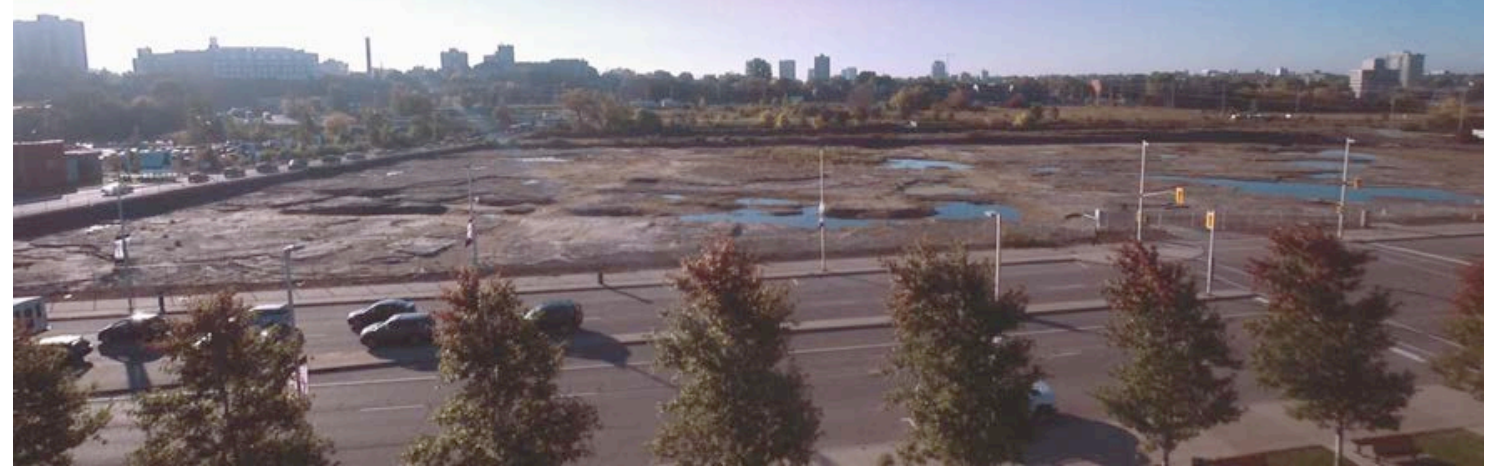

Photo 4: LeBreton Flats north parcel, looking south from the Sir John A. MacDonald Parkway (NCC, 2014).

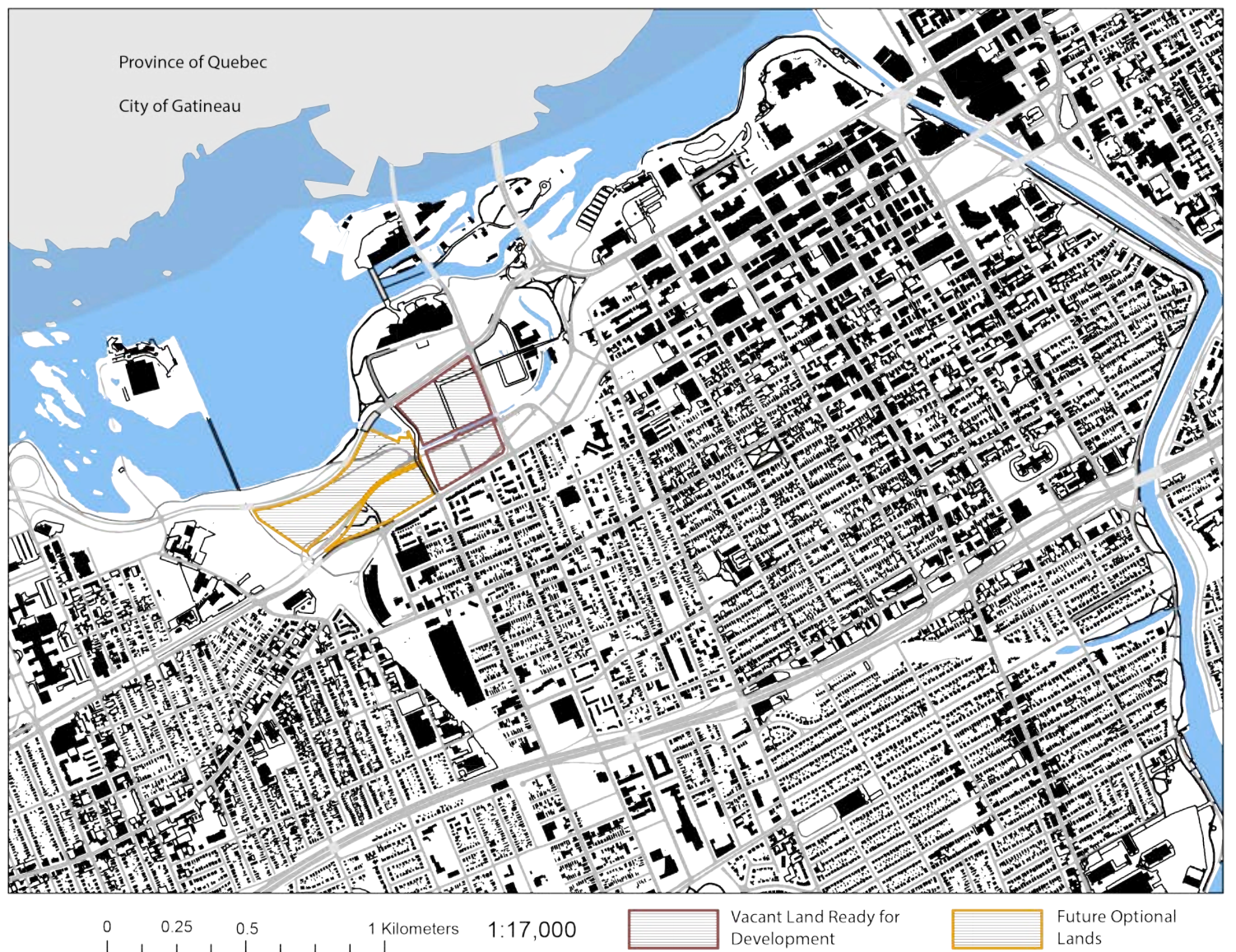

Figure 2: Built form and the developable and optional lands of LeBreton Flats

*not to scale due to formatting 
Photo 5: Built Form of Ottawa and the site of LeBreton Flats (NCC, 2007)
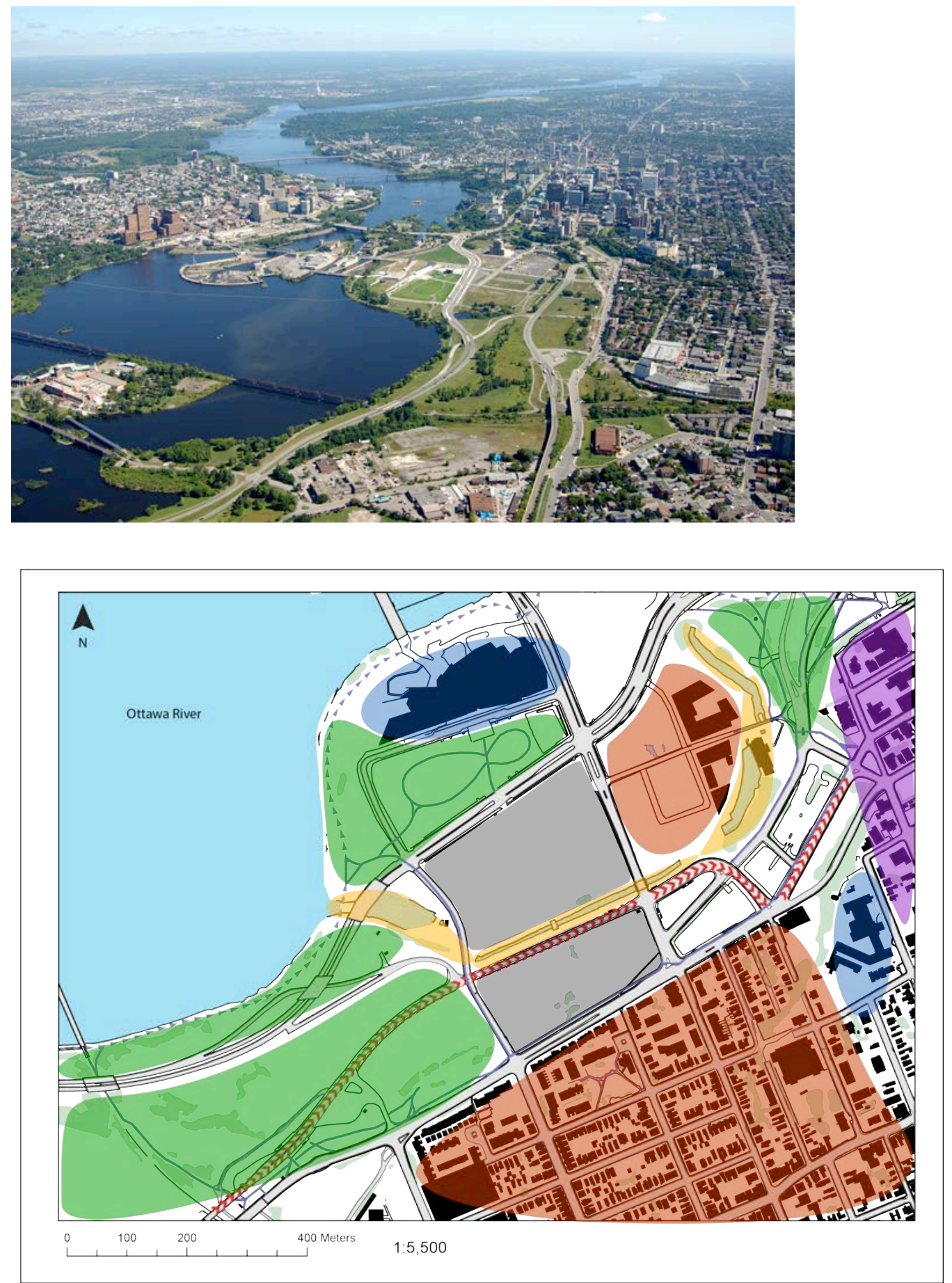

Land Use

Analysis Map

Legend

Developable

Land

(1)) OC Transpo

Transitway

Residential

Open-Green

Space

Institutional

Use

Designated

Heritage

Mixed

Employment

and Residential

Trail

Figure 3: Land use analysis map

*not to scale due to formatting

LeBreton Flats has a long history spanning almost 200 years in Ottawa. The area has a historically and culturally significant past with the first Europeans settling in the area in the early 
$19^{\text {th }}$ century. However, the Flats obtained its name from the ex-army officer Captain John LeBreton, who first bought the land when he came to Ottawa in 1820 (Bond, 1961; Ross, 1927).

LeBreton Flats was a busy economic hub with timber mills and lumber piles near the Chaudière Falls. Stone and wooden homes housed the entrepreneurs and labour force of the area during the latter half of the $19^{\text {th }}$ century. From the late $19^{\text {th }}$ and early $20^{\text {th }}$ centuries, LeBreton Flats consisted of industrial complexes of wood mills and supporting businesses employing thousands of people in Ottawa and providing the materials that helped Canada emerge as an industrial nation (NCC 2014b). This employment contributed to growth in the local and national economy as many community businesses formed as a result of the industrial labour needed (NCC, 2014b). The community itself provided residents with the opportunity to live close to their place of work; consequently, mill workers were much more sedentary than other profes-

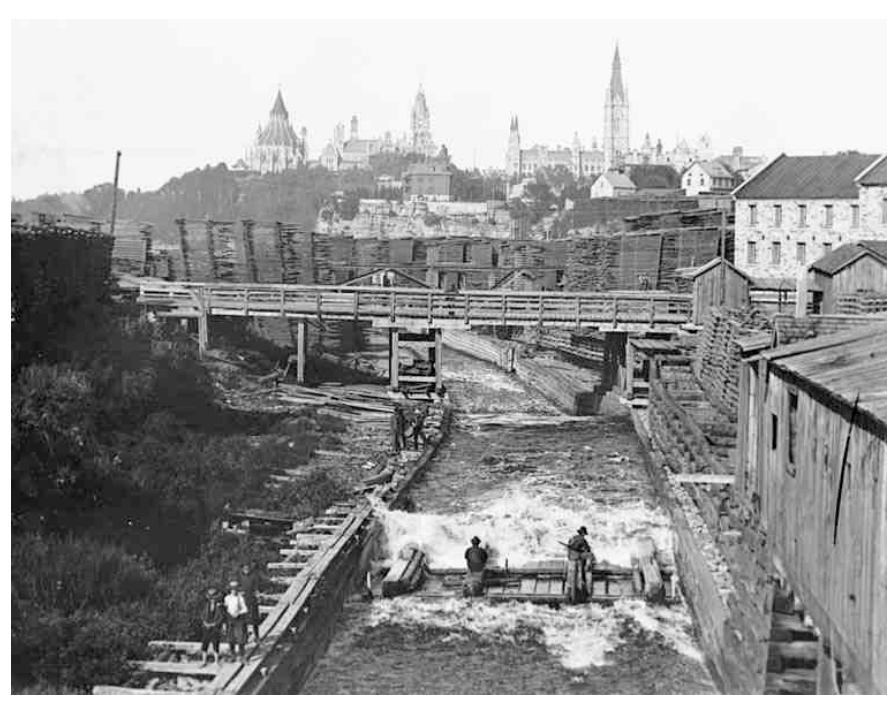

Photo 6: Collections Canada (2007). Timber Slide, facing east to Parliament Hill.

sions located in the area at the time (NCC, 2014b; Taylor, 1986). LeBreton Flats was the community of the "industrial workingman" due to the many occupations required to support the timber and mill industry and attracted immigrants from around the world contributing to the Flats' diversity and character (Taylor, 1986; NCC, 2014b). Victorian houses characterized the neighbourhood allowing residents to interact with neighbours on their front porches. LeBreton Flats came to be known as a "friendly, close-knit, outward facing community" (NCC, 2014b). 
Unfortunately, the depression of the early 1890s and the Great Fire of 1900 devastated LeBreton Flats and destroyed many houses and businesses (Taylor, 1986; NCC, 2014b). The community eventually rebuilt itself, but due to a decline in demand for lumber at the turn of the century, by the 1950s the land contained nothing more than derelict mills and the remnants of a once-thriving industrial community by the 1950s (Taylor, 1986). Therefore, the land was bought and cleared by the National Capital Commission for a major urban renewal project. Under the NCC's possession, LeBreton Flats has laid vacant due to contamination of previous industrial

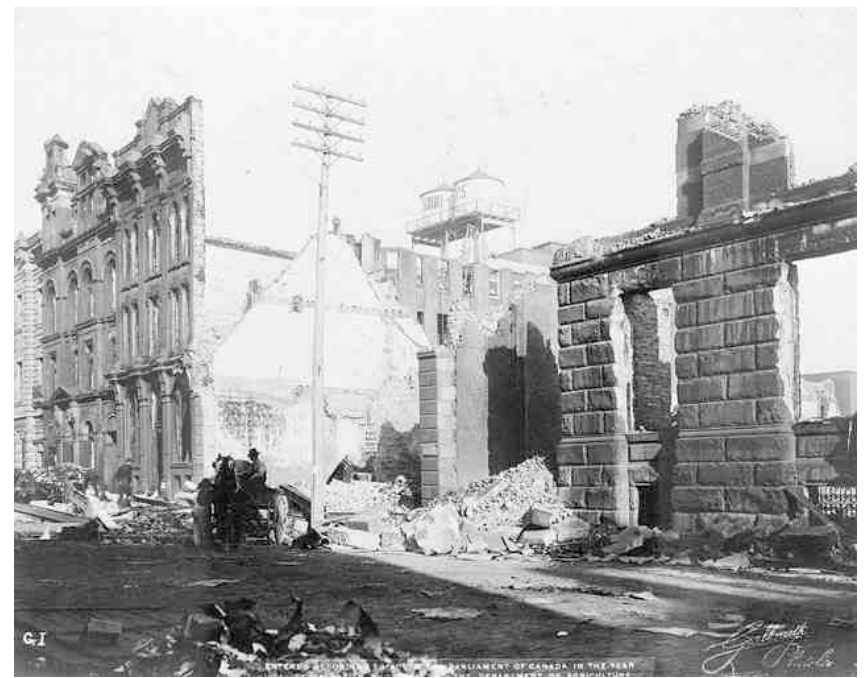

Photo 7: Collections Canada (2007). The eastern limit of the destruction on Wellington Street from the Great Fire of 1900

activities for more than half a century.

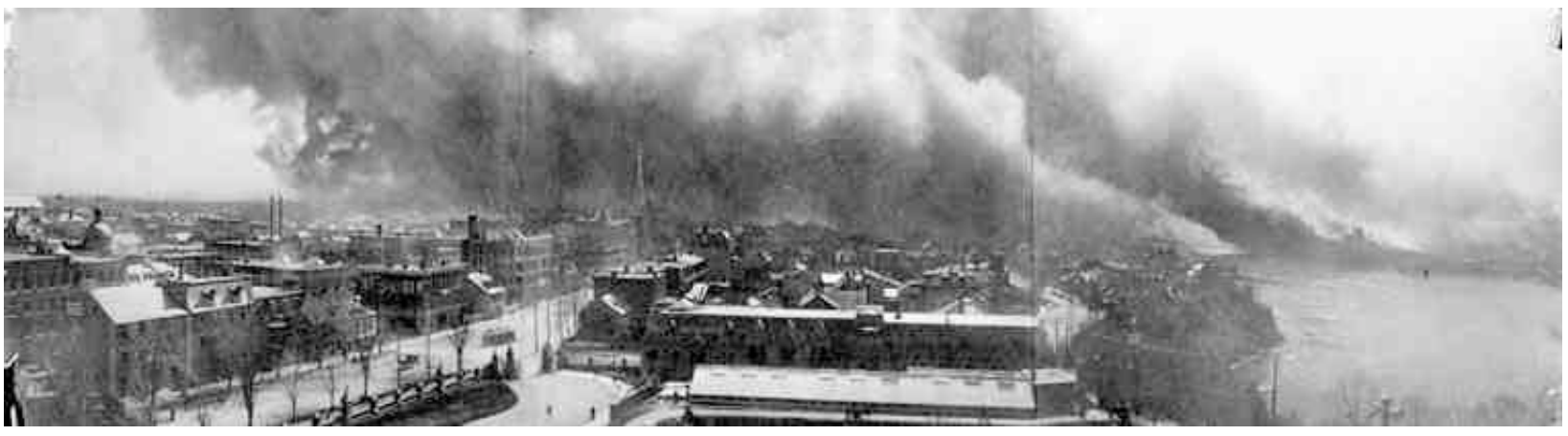

Photo 8: Collection Canada (2007).1900 fire as seen from Parliament Hill as it crossed the Chaudière into LeBreton Flats.

As noted in previous chapters of this report, the success of brownfield redevelopment and the theories and practices of quality urban design can be used to create a workable and culturally thriving community, or even a district in the case of LeBreton Flats. Considering that the land is 
vacant and ready for development, the former industrial heritage of this land and its prime waterfront location represents a great opportunity for developers to create a new and innovative neighbourhood. This project would reimagine the future of LeBreton Flats from its present status as a vacant and underutilized brownfield site.

\section{Section 3.2 - Important Developments in the Flats}

In 2012, the City of Ottawa approved the largest transit infrastructure project in the capital's history. The Confederation Line is the first phase of the City of Ottawa's light rail transit system now under construction that will provide rapid transit service between Tunney's Pasture (west of downtown Ottawa) to Blair Station (east of downtown Ottawa). A portion of the Confederation Line will run in a subway under the downtown core (MacNair, 2014). The line is currently under construction and is scheduled for completion in May 2018, with boring of the underground section having begun in October 2013 (City of Ottawa, 2015d). At the cost of about \$2.13 million, Confeder-

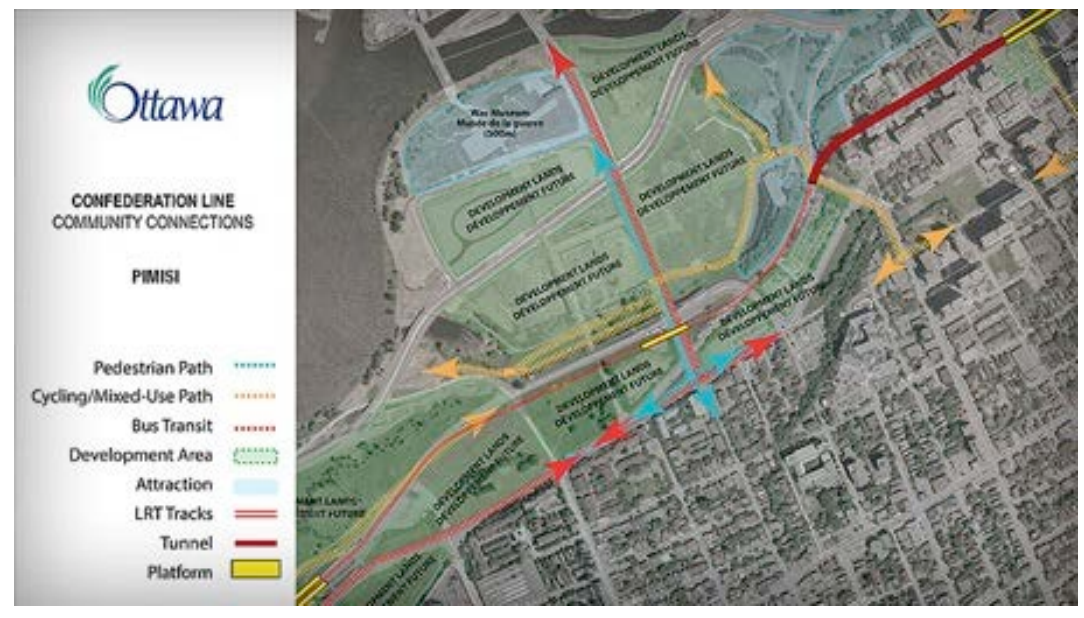
ation Line will have the capaci-

Photo 9: City of Ottawa (2015). LeBreton Flats with Confederation Line and integrated community connections from OC Transpo.

ty to transport 24,000 passengers per hour, both east and west, between Tunney's Pasture and Blair Station (Robinson, 2014). A station will be located in LeBreton Flats and will be known as Pimisi Station, a name chosen to honour the Algonquin people (OC Transpo, 2015). This station will have a profound affect on future development of the Flats since it provides the ability to create transit-oriented development (TOD) in the area. The Confederation Line fits into the vision 
and policies set out by the City's Transportation Master Plan (TMP) (2013) which calls for the need to integrate rapid transit into the city core, to create transit oriented developments to support transit lines, and to provide such transit services to communities and employment areas. It also highlights the need to use energy more efficiently from renewable sources, as set out in the City's Strategic Plan by converting the City's diesel-powered bus rapid transit system to electric-powered light rail (Transportation Master Plan, 2013).

The Rideau Transit Group (RTG), an association of firms assembled to design, finance, build, and manage the Confederation Line, was selected by the City in 2012. All three levels of government have provided funding for the line with $\$ 900$ million being provided by the City of Ottawa, $\$ 600$ million by the Government of Ontario and $\$ 600$ million by the Government of Canada (Robinson, 2014). It is worth noting that many of the lands over which the Confederation Line will pass are crown lands owned by the federal government, including LeBreton Flats. Also the public-private partnership between the City of Ottawa and the Rideau Transit Group is an example of when public agencies and corporate companies join together under contractual arrangements to complete a mass infrastructure project.

On February 18, 2015, the NCC announced the shortlist proponents chosen to prepare detailed development proposals for LeBreton Flats. Each proponent will be granted $\$ 75,000$ as a financial contribution to complete a proposal with the successful proponent to be announced in mid-2016. The shortlisted proponents include:

1) "Claridge Homes proposes indoor and outdoor concert facilities, cultural enterprises surrounded by green spaces, and residential and commercial developments.

2) Devcore Group proposes a concept with multiple cultural institutions developed around a grande allée, green spaces, and residential and commercial developments.

3) Focus Equities proposes to house the headquarters of an international organization, accompanied by cultural venues, green spaces, and residential and commercial developments. 
4) Rendez Vous LeBreton Group proposes a major event centre for sports and entertainment performances, complemented by green spaces, and residential and commercial developments." (NCC, 2015d)

With the NCC's call for proposals for redevelopment, the construction of an anchor institution may become possible with the help of a consortium of developers willing to enter into a public-private partnership with the government agency. Such a partnership has the potential to result in infrastructure and design quality that is innovative and unique to the area as specialists (urban planners, urban designers and civil engineers, etc.) may be hired to produce a master plan for LeBreton Flats. Additionally, the introduction of rapid transit through LeBreton Flats will provide the ability for residents from across the city to travel to the area with ease. The Confederation Line will allow residents that live in other areas of Ottawa to visit LeBreton Flats by stopping at Pimisi station. Considering that the site is crown land, the inclusion of an anchor institution and/or government office space in the development would allow workers, future residents, and tourists alike to utilize the future LRT system. A key feature of compact urban design is the inclusion of transit-oriented development. Therefore, the redevelopment of LeBreton Flats will capitalize on this large-scale municipal infrastructure project. 


\section{Chapter 4: Policy Overview}

\section{Section 4.1 - The Provincial Policy Statement 2014, the Planning Act and Ontario Regula- tions}

At the provincial level, the 2014 Provincial Policy Statement (PPS) is the provincial framework that sets the background for planning at the regional level and includes many sections that are applicable to the redevelopment of LeBreton Flats. The PPS, which is legislatively issued under Section 3 of the Ontario Planning Act, states that any development "shall be consistent with" the policies stated in the PPS. The PPS sets the direction for planning in Ontario by discussing the need to create healthy communities that are sustained by efficient development and land use patterns. This includes the provision of a mix of residential and non-residential uses at an appropriate range of densities and intensities, as well as parks, open spaces, and recreational uses. Three key policy statement principles underline the PPS, which tries to find a balance between economic, social and environmental benefits. These principles are shown in the chart below:

Table 3: Summaried PPS 2014 Principles

\begin{tabular}{|l|r|}
\hline PPS 2014 Principles & Description \\
\hline $\begin{array}{l}\text { Creating and Building } \\
\text { Strong Communities }\end{array}$ & $\begin{array}{l}\text { Effective use and management of land through efficient devel- } \\
\text { opment that optimizes land, resources, and public infrastructure } \\
\text { investment and public services. Providing a mixture of housing } \\
\text { types, densities, transportation options, recreation and parks and } \\
\text { open spaces to meet the needs of citizens. Protecting employ- } \\
\text { ment areas that serve as economic drivers for urban centres. }\end{array}$ \\
\hline $\begin{array}{l}\text { Protection and Wise } \\
\text { Ranagement of }\end{array}$ & $-\begin{array}{l}\text { Protecting hydrological, agricultural, and aggregate resources as } \\
\text { well as natural and cultural/archaeological heritage resources to } \\
\text { ensure economic prosperity and environmental well-being. }\end{array}$ \\
\hline $\begin{array}{l}\text { Protection of Public } \\
\text { Health and Safety }\end{array}$ & $\begin{array}{l}\text { Directing development away from lands deemed as unsafe to } \\
\text { public health and safety due to natural or human hazards that } \\
\text { may also cause property damage. }\end{array}$ \\
\hline
\end{tabular}
Adapted from: PPS (2014), OMMAH (2015) and Fotenn (2012).

Brownfield policy is focused on efficiently reusing land through intensification, infill development, or adaptive reuse. Policies also focus on creating communities, which are diverse 
in use and provide an array of building types and services. There is also discussion about the need for coordination of different government agencies due to the fact that the site is contaminated by human-made hazards. The PPS supports the remediation and redevelopment of brownfield sites under section 1.7 Long-Term Economic Prosperity through policy 1.7.1 e) "promoting and the redevelopment of brownfield sites" (PPS, 2014; pp. 20). However, remediation for general public health and safety is just one aspect of how LeBreton Flats connects to provincial policy. Due to the historical past of the area, any development should consider the cultural landscape of LeBreton Flats through consultation with aboriginal communities that may have ties to the land and thoughtful urban design. Redeveloping LeBreton Flats provides more than just decontaminating a large parcel of land for economic use. It is about ensuring good planning practices by creating a new urban community that compliments the existing surrounding uses, using efficient land development and supportive surface and rail line transit in addition to limiting public and environmental health hazards from previous industrial use.

Additionally, at the site level brownfields have specific policies that affect their redevelopment. The legislative and regulatory framework and requirement for brownfields in Ontario falls under Ontario Regulation 153/04 - Records of Site Condition. This regulation explains and defines the process, which a proponent must follow to ensure the proposed property is safe and can be cleared for redevelopment. There are two approaches to cleaning up contaminated sites. The proponent can either restore the site to generic Site Condition Standards or prepare a Risk Assessment. The Risk Assessment is chosen when restoration cannot meet Site Condition Standards. Therefore the assessment looks at site-specific conditions and the potential risk to human and wildlife health and acceptable risk (AMEC Earth and Environmental, 2011). 


\section{Section 4.2 - Capital Urban Lands Master Plan and Role of the NCC}

The Capital Urban Lands Master Plan 2014 (CULMP) is the regional, specialized capital land-planning document that sets the visions for planning the federal urban lands in the capital region of Ottawa and Gatineau (NCC, 2014a). This CULMP is part of the NCC's Guiding the Way to 2067, which holds a strategic direction for planning in Canada's capital. Its focus is on creating a dynamic Capital while promoting its symbolic representation, fundamental role and physical features (NCC, 2014a). LeBreton Flats is owned by the National Capital Commission as capital land meaning that it falls under the policies of the CULMP. The CULMP does not contain any area-specific polices for the Flats; it simply guides capital planning for the different sectors of Ottawa to encourage a vibrant, symbolically rich Capital realm. As a regional plan, the CULMP incorporates and refines the recommendations of the Core Area Sector Plan 2005, the original plan containing policy directives for LeBreton Flats calling for a mixed use, independent community that links the Flats to the Central Business District and surrounding cultural and historical sites. Under the Core Area Sector Plan 2005, three broad policy categories were provided for development in the Flats:

Table 4: LeBreton Flats policies as stated in the Core Area Sector Plan, 2005

\begin{tabular}{|c|c|}
\hline $\begin{array}{l}\text { Preserve and enrich } \\
\text { character }\end{array}$ & $\begin{array}{l}\text { - Well designed mixed-use neighbourhood with a range of } \\
\text { building types and uses (high-rise residential buildings, office } \\
\text { and commercial uses). } \\
\text { - Well connected public open spaces. } \\
\text { - Additional services and amenities to support the area. }\end{array}$ \\
\hline Improve connectivity & $\begin{array}{l}\text { - Provide pedestrian connections to the central business district, } \\
\text { the escarpment, Sparks Street Mall, the Canadian War muse- } \\
\text { um and other nearby areas. } \\
\text { - Improve way-finding to landmarks and cultural institutions. } \\
\text { - Development of parks and open spaces that connect with ex- } \\
\text { isting open spaces. }\end{array}$ \\
\hline $\begin{array}{l}\text { Enhance use, employ- } \\
\text { ment, animation and } \\
\text { safety }\end{array}$ & $\begin{array}{l}\text { - Support heritage through the creation of public spaces along } \\
\text { the aqueduct. } \\
\text { - } \quad \text { Development of a National Cultural Institution on the site. }\end{array}$ \\
\hline
\end{tabular}


The NCC is the current land title owner of all the land in LeBreton Flats and therefore will work together with the City of Ottawa on any development that will occur there.

\section{Section 4.3 - Ottawa's Official Plan}

Ottawa's Official Plan instructs for the intensification of the downtown core and the efficient use of land, especially within the boundaries of Ottawa's Greenbelt. It also sets out the directive for community improvement plans and criteria that must be considered when designing a development on brownfield land. Development at LeBreton Flats will intensify a substantial portion of land currently designated as Central Area in Ottawa's Urban Policy Plan (Schedule B) under Official Plan Amendment 143 (City of Ottawa, 2014). The Central Area policies of the Official Plan call for intensification of the downtown area in order to discourage urban sprawl, protect the environment and encourage a vibrant, culturally diverse city that fosters economic growth in Canada's Capital. Additionally, the National Capital Greenbelt encompasses the core of Ottawa to protect natural heritage and resources while encouraging development to occur within the boundaries of the greenbelt.

Section 1.11 LeBreton Flats of Ottawa's Official Plan speaks to the planning policies that are set out at the municipal level for this area of the city. The policies in this section make specific reference to what is needed for redevelopment of the area as a mixed-use, people oriented community with viable transit and open space. According to Section 1.11.3.1, City Council will approve, support and encourage development of publicly-oriented uses such as museums, art galleries and offices, accompanied by at grade retail and entertainment uses. Section 1.11.3.2 Greenway System stresses the importance of protecting and providing access to the waterfront corridor and green, open spaces. In terms of urban design, Section 1.11.4.4 states:

"City Council shall require that a set of broad Urban Design Guidelines for the entire LeBreton Flats area be prepared, in order to assist in the design of development, rights-of-way 
and open spaces, and their interrelationships, in an integrated and cohesive manner, prior to the initial submission of an application for development approval; and, that such urban design guidelines shall consider Alternate Design Standards and Traffic Calming." (City of Ottawa, 2014)

\section{Section 4.4 - Ottawa's Brownfields Community Improvement Plan}

The City’s Brownfields Redevelopment Community Improvement Plan (CIP) is a detailed document concerning the redevelopment of brownfield lands. The CIP is based on the Ottawa Brownfields Redevelopment Strategy that sets out the general policy framework to guide brownfield redevelopment programs. The CIP for Ottawa acts as the vehicle to implement the Ottawa Brownfield Redevelopment Strategy and is achieved through financial incentive programs (study grants, tax assistance, and tax increment equivalent grants, etc.) and a municipal leadership strategy encouraging the remediation and adaptive reuse of brownfield sites (City of Ottawa, 2010).

Under Ottawa's Brownfield CIP, brownfield redevelopment is considered a 'priority project'. Since the remediation of sites creates a cleaner and safer environment by reclaiming previously industrial land, brownfield redevelopment has positive effects of curbing urban sprawl by reusing derelict, underutilized properties, increasing property values and creating new employment during construction, and afterwards, depending on the use of the site (City of Ottawa, 2010). 


\section{Chapter 5: Site Analysis}

\section{Section 5.1 - Site Characteristics and Analysis}

As previously noted, Lynch (1960) proposed five functional elements for place making in the city, including Paths, Edges, Nodes, Districts, and Landmarks. This method of analysis was used to analyze LeBreton Flats and surrounding areas as displayed in Figure 4. Paths are areas where people move along, the most easily identifiable path being the Trans-Canada trail located to the north of LeBreton Flats along with the many other pedestrian and cycling paths in the area. The main roads of Booth Street, Preston Street, and the Sir John A. MacDonald Parkway would also serve as paths for cars and pedestrians. The dedicated Transitway route through the Flats can also be considered a path. Overall, these paths are the predominant means by which people access the area from other parts of both Ottawa and Gatineau and move through the site.

Edges are physical, linear spaces that consist of boundaries, which people normally do not travel along. The shoreline of the Ottawa River would be the most easily identifiable edge of LeBreton Flats. Similarly, Albert Street could be thought of as both a path and an edge as people travel along the street, however, it also demarcates the southern most border of the Flats.

Districts such as Byward Market in Ottawa or Distillery District in Toronto are mediumto-large areas which people 'mentally' enter in their mind and are easily visible due to their identifiable character (Lynch, 1960; Sternberg, 2000). LeBreton Flats is easily identifiable from both the inside and outside even though it is a district waiting to be developed and diversified. This is because the Flats are well known to be flat and directly adjacent to the Ottawa River. Its location plays a central role in its identity and character. The area also contains the Canadian War Museum and hosts the famous weeklong Blues Festival every July.

The intersections of Booth Street and the Sir John A. MacDonald Parkway and the Transitway LeBreton bus stop are nodal areas and see the largest amount of pedestrian volume, 
especially during rush hour. The convergence of paths at these nodes ensures that people will likely interact with one another and the local environment. Nodes are related to paths because all the streets mentioned are pathways in which people use to transverse the Flats. This area can then be related to districts as people travelling along these paths that converge into the nodes, which are central to the heart of the Flats.

As stated above, landmarks act as external point of references for individuals and provide a visual clue of direction. An example would be the Peace Tower at Parliament Hill acting as a symbol of direction for individuals exploring a city. However, the most easily identifiable landmark of LeBreton Flats is the Canadian War Museum, especially with its unique architecture that allows the structure to blend nicely with its surroundings.

During site observations in the spring, summer, and fall of 2014, traffic volume was highest during morning and afternoon rush hour. This was particularly exacerbated by the construction occurring on Albert Street in order to widen the street to temporarily accommodate the Transitway during construction of the Confederation Line. Traffic occurred on all three major roads, Albert Street, Booth Street and the Sir John A. MacDonald Parkway. Fortunately, the Transitway provides a dedicated bus route without disrupting traffic along major streets. Traffic also included pedestrian activity, especially at transit stops. Pedestrian were spotted at the perimeter of the site, especially along Booth Street and Albert Street with the dedicated bike path. Activity in these areas was probably influenced by the transit stops nearby allowing people to access the bus stops at the Transitway-Booth Street intersection and along Albert Street with ease. 


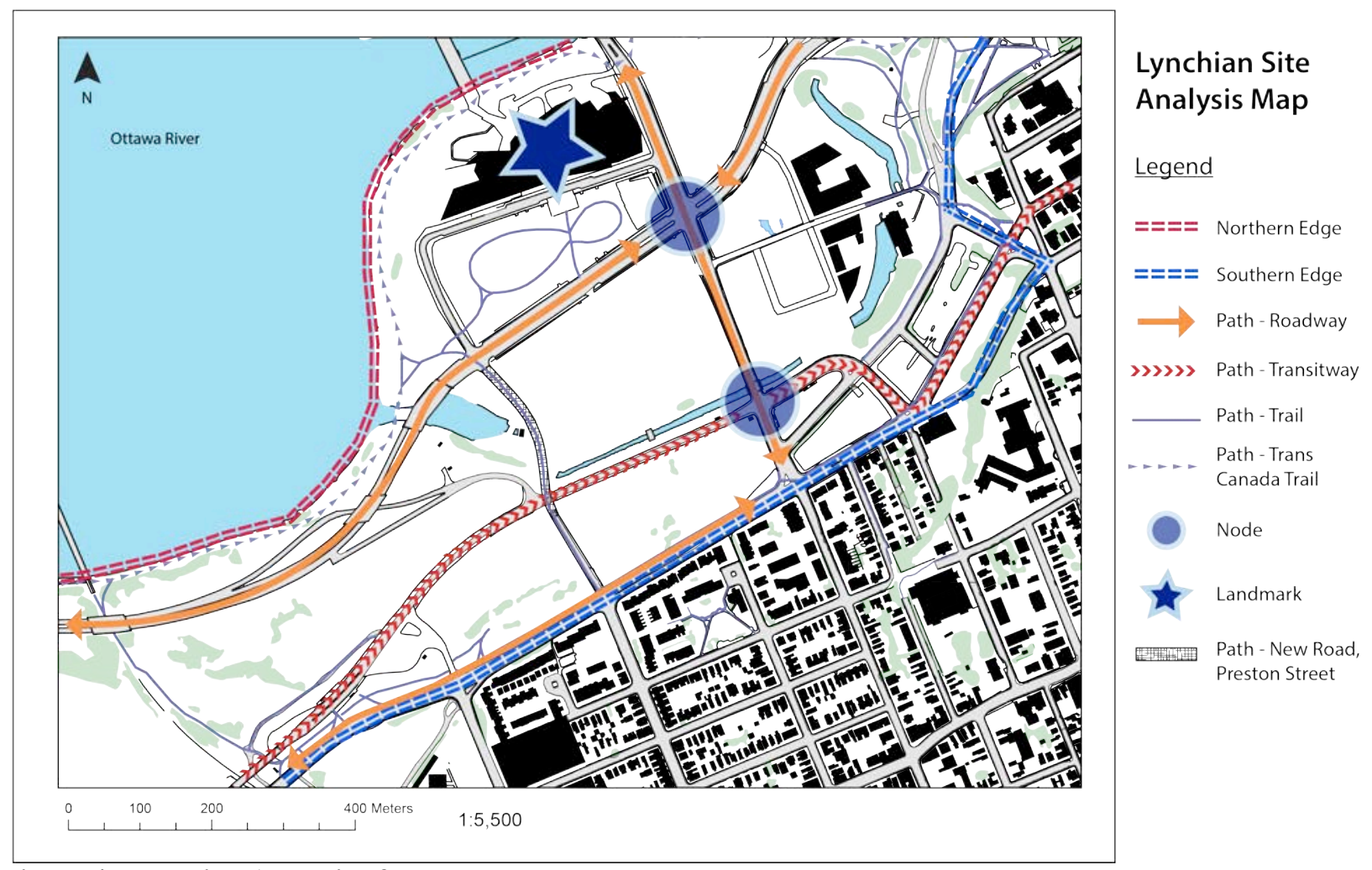

Figure 4: Lynchian Analysis of LeBreton Flats

*not to scale due to formatting

\section{Section 5.2 - Urban Design Case Precedents for LeBreton Flats}

The redevelopment of LeBreton Flats provides an opportunity to analyze other relevant developments in Canada as well as internationally. There are many brownfield examples from across the world with some sites enabling adaptive reuse of post-industrial buildings while other derelict, vacant sites have been or are currently being transformed into new developments. The following section provides examples of case precedents that serve as examples of brownfield redevelopment and the capacity to do something creative and unique with LeBreton Flats.

\subsubsection{West Don Lands and Toronto's Pan Am Athletes Village}

The West Don Lands redevelopment is perhaps the most innovative use of former brownfield land. Development is currently under way and will be completed by the summer of 2015 for the Pan Am Games. The area will provide accommodations for athletes who will be in Toronto 
to compete in the games and will then be turned into residential apartments after the games have finished. However, permanent residents have already moved into other sections of the West Don Lands, including River City.

The West Don Lands Precinct Plan focuses on creating a new mixed-use environment emphasizing urban living and incorporating many of the design characteristics of existing neighbourhoods that surround the site. Some buildings will feature retail ground floor uses with residential units above while others will function as live/work studios all varying in building height from four-storey town houses, to eight-storey loft-type units, to buildings

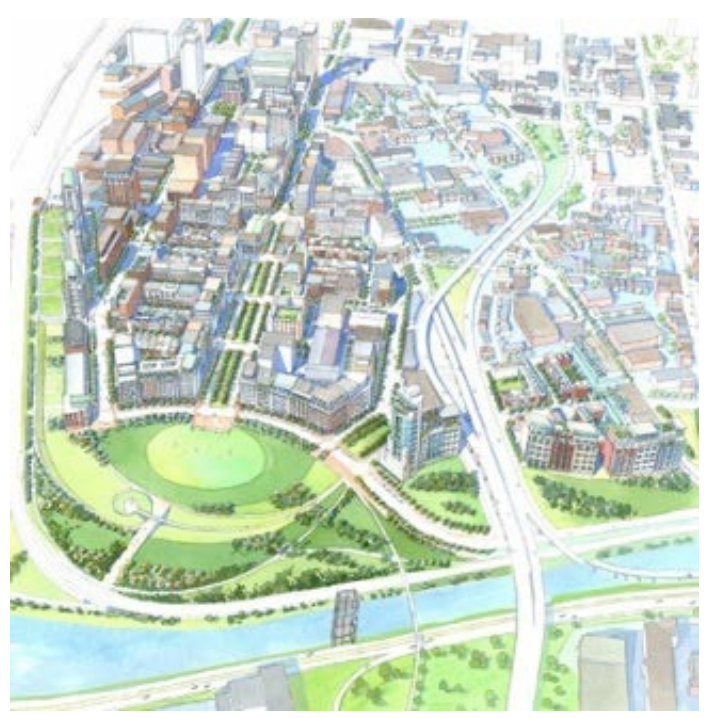

Photo 10: DTAH. (2015). West Don Lands. reaching 24 storeys (Urban Associates, 2005). Other physical design principles for the area emphasize continuous building surfaces along the primary streets in the precinct accompanied by garden like streets lined with trees. In this case, a new park located at the mouth of the Don River anchors the West Don Lands development. It provides an access point into the downtown area and purposefully reinforces the public realm of the precinct. Additionally, the neighbourhood park will connect to the Lower Don Trail providing recreational and leisure opportunities for residents. What is interesting about the West Don Lands is that the design of the master plan has separated the areas into five different neighbourhoods. However, it has integrated the design and character of adjacent neighbourhoods into the new design for the new sections of the West Don Lands. For example, the Front Street neighbourhood will be in a similar character and physical texture to Old York and the St. Lawrence neighbourhood, whereas the Mill Street neighbourhood 
will incorporate the scale and features of the adjacent Distillery District neighbourhood (Urban Associates, 2005).

The West Don Lands development was chosen as a case study because of the design of the precinct. Land use design incorporates streetscapes and built form with the natural environment through the parkland dedication and trail integration. It is important to understand that the layout is purposely designed to lead to the open space made available to the new precinct. Additionally, the design of the West Don Lands thoughtfully incorporates features and details of adjacent historic neighbourhoods. This is an example of how a large-scale development is woven into an existing urban area. Any development at LeBreton Flats should consider incorporating features of the surrounding neighbourhoods if it is to be a successful development that will blend in with the existing urban fabric.

\subsubsection{London's Royal Docklands}

The London Royal Docklands are a former heavy industrial district situated on the banks of the Thames River in East London (Urban Strategies, 2015). The entire area of the Docklands stretches some 5,500 acres (Benton-Short and Short, 2008). With development spanning from 2001 to 2012, Urban Strategies - a planning consulting firm from Toronto

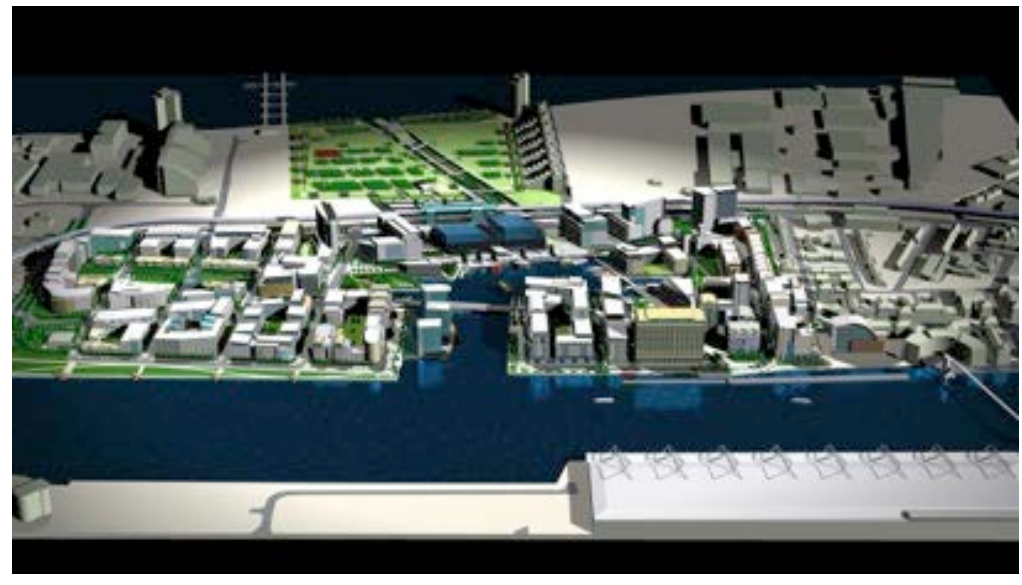

Photo 11: Urban Strategies (2015). Rendering of Silvertown quays in London's Royal Docklands.

- created master plans and proposals for 570-acres of land on the Docklands. These areas are host to 40,000 residential units with the capacity to provide 20,000 new jobs due to commercial 
space allotment (Urban Strategies, 2015). Overall, the redevelopment of the London Docklands has changed it from an underutilized post-industrial area to a vibrant multi-use complex with office space, residential buildings, shops and museums (Benton-Short and Short, 2008).

Urban Strategies was the lead consultant providing the strategy to transition the Royal Docks into a mixed-use, transit-oriented development. Site-specific areas that Urban Strategies worked on included master plans for the redevelopment of Silvertown Quays, Canada Water, and the ExCel Exhibition Centre. Silvertown Quays is a 60 -acre site $(24$ hectares) featuring mixed-use commercial and residential buildings with an active town centre (Urban Strategies, 2015), whereas the ExCel Centre features an ex-

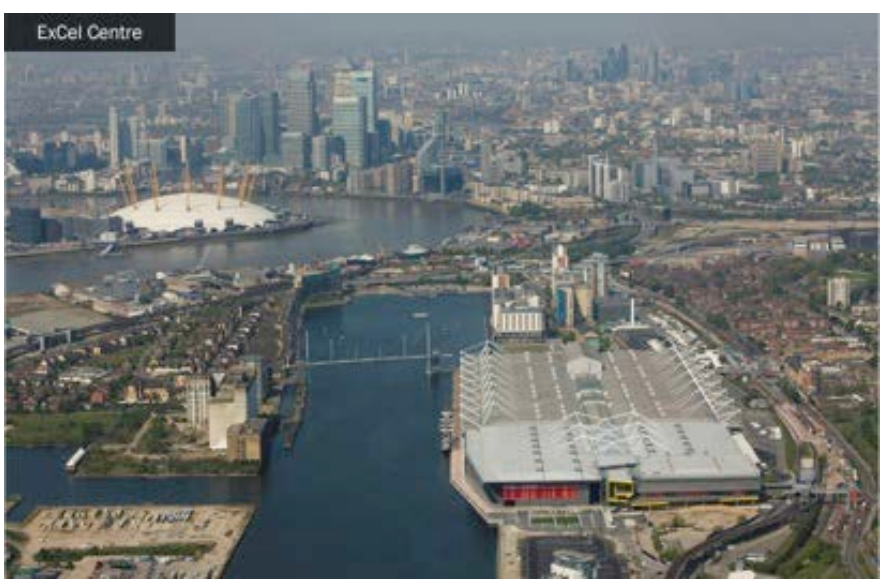

Photo 12: Urban Strategies (2015). ExCel Centre in London's Royal Docklands.

hibition and conference facility making it an anchor use and includes a master plan that anticipates future growth in the area. Canada Water was an underutilized dock that required regeneration and redevelopment in the London Docklands. The vision was to have a new urban community hub reintegrated to its surroundings anchored by retail and sports facilities including an aquatics centre and public library (Urban Strategies, 2015).

The London Docklands was chosen as a case study because it has been an ongoing redevelopment of post-industrial land on the waterfront. It also includes the use of flagship anchor institutions as a method of redeveloping urban areas while providing commercial and residential uses. 


\subsubsection{Oslo’s Opera House, Norway}

Olso's waterfront was in dire need of redevelopment due to industrial processes in the past. The city decided to site its new opera house on the waterfront to create a new cultural space to attract people to the area. Opened in 2008, the Norwegian Opera and Ballet Company was located in the heart of Oslo on the waterfront of the borough of Bjorvika, a run-down area of the city in need of regeneration (Smith and von Krogh Strand, 2011).

According to Smith and von Krogh Strand (2011), the opera house was understood as a cultural and national symbol but also a catalyst of urban regeneration on the waterfront. The exterior of the opera house was constructed with white stone in order to make the building stand out on the urban waterfront (Smith and von Krogh Strand, 2011). Overall the

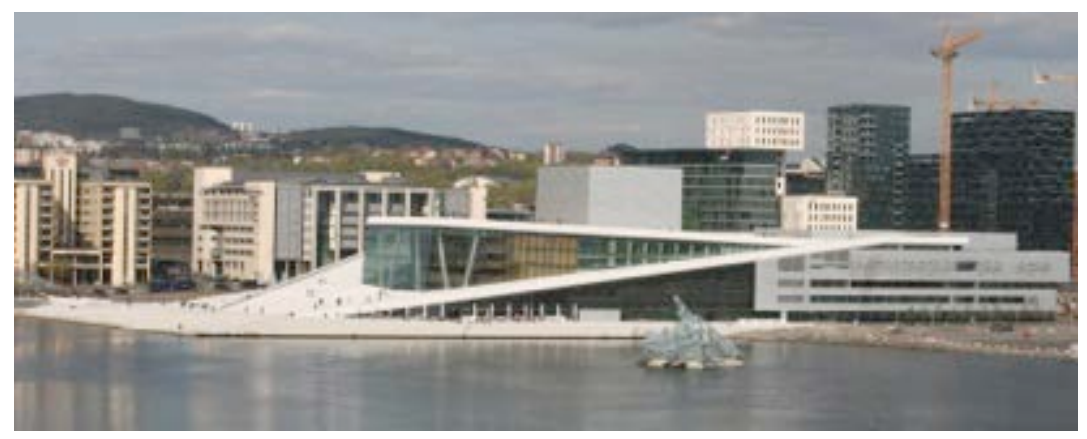

Photo 13: GAD (2011). Oslo Opera House.

building is seen as a flagship for opera and cultural transactions driven by the motivation to redevelop a declining urban area and reconnecting the city and sea together (Smith and von Krogh Strand, 2011). Through their study and interviews with stakeholders, Smith and von Krogh strand (2011) discovered that the opera house is more of a destination than an attraction as people do not come just to see the architectural design of the building but to experience and gather by the waterfront.

Oslo's Opera House presents a case study for LeBreton Flats for a cultural institutional anchor also serving as a public space on the waterfront. Since there is already the Canadian War Museum on the waterfront north of the developable parcels, any development has to accommo- 
date the museum. It also has to ensure that another cultural institution does not overwhelm the area but rather complements the existing land use and built form.

\subsubsection{Rogers Place and the Edmonton Arena District, Edmonton Alberta}

Edmonton Arena District (EAD) is a new development located in downtown Edmonton focused on being the "city's hub and heart" (EAD JV Inc. 2015). A joint venture between Katz Group and WAM Development Group, the 25-acre EAD development will link four urban quadrants in the city core (WAM Development Group, 2015). While the site is much larger than the current developable portion of LeBreton Flats, the EAD is a prime example of redeveloping derelict brownfield land that is being redeveloped in the city core of Edmonton. Although the site is currently under construction, the EAD was selected as a case precedent due to its integration of different land uses and anchor institution of the Rogers Place Arena and public plaza. By fall of 2016, the Rogers Place Arena will be the new home of the Edmonton

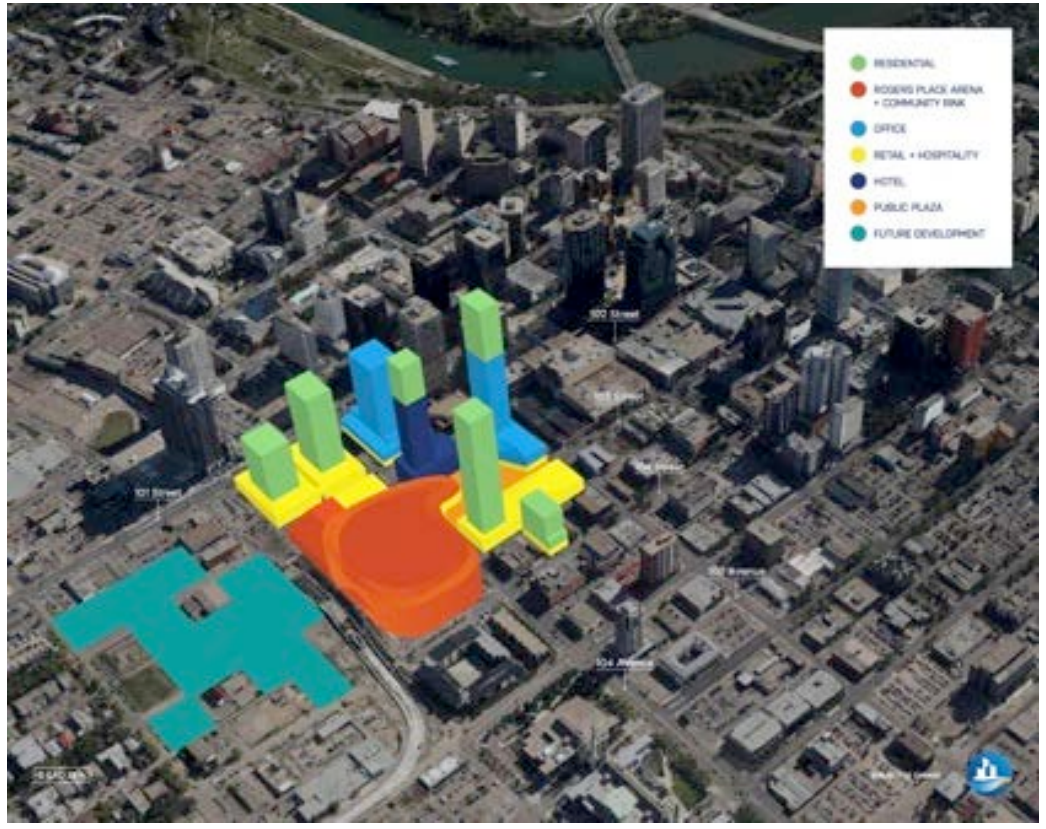

Photo 14: EAD (2015). Edmonton Arena District concept map.

Oilers hockey team and will function as an entertainment and event venue (EAD JV Inc. 2015). In addition to Rogers Place, Phase 1 of development will also provide a Community Rink, parkades and the first office tower. The next phase of the development, Phase 1X, will provide further expansion featuring an additional office tower, the Delta Hotel, condominiums, rental 
apartments and retail and commercial attractions (EAD JV Inc. 2015). Within the centre of the development is the public square, which will connect citizens and residents living in the area to all near by amenities. Phase 2 will expand further north of the site to complete the entire master plan.

Furthermore the EAD focuses on providing mixed-use development to encourage diversity of land use and activity within the urban core. This form of land use is incorporating a variety of residential types, commercial office towers, commercial retail opportunities, public realm through parkades and the Public Square, and entertainment anchors as well as community uses through the Community Rink. The EAD will also be fully serviced by multiple transit options making it a transit-oriented development. Five LRT stations are located within walking distance of the community

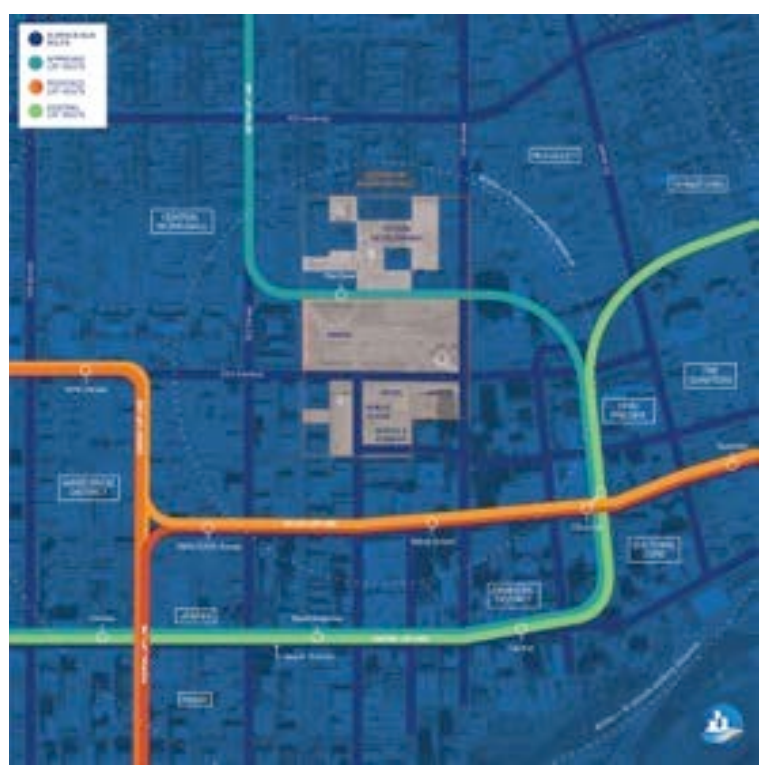

Photo 15: EAD (2015). Edmonton Arena District with integrated transit.

in addition to the surface transit network that completely services the EAD with bus routes along all edges of the new development (EAD JV Inc. 2015). The MacEwan LRT station will be located centrally in the development adjacent to Rogers Place arena. The EAD will also link transit, bike paths, the Pedway System and MacEwan University, MacEwan LRT station, downtown core and other surrounding districts close to the EAD. New parking facilities will also be provided in surface lots and in below-grade underground parking to accommodate motor vehicle activity in the area. The addition of 3000 new underground parking stalls will provide more space for vibrant, mixed-use street life that provides retail and public space in the EAD. 
The site will feature commercial opportunities with LEED Gold standard office towers providing retail options and business growth in downtown Edmonton. Retail options will feature entertainment and hospitality uses such as boutique stores, restaurants, and cafes expecting to attract 3 million people a year due to the easily accessible transportation options to the area. Office space will be able to take advantage of nearby retail spaces creating an integrated business environment to grow in the downtown

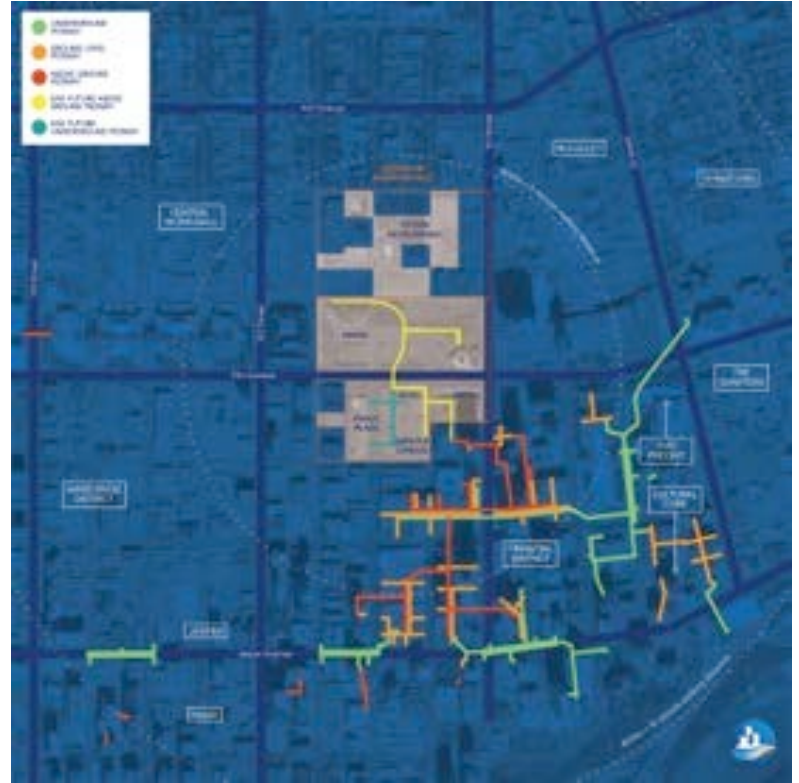

Photo 16: EAD (2015). Edmonton Arena District with integrated pedestrian pathways from the downtown core. core.

The EAD was chosen as a case study due to the master plan integrating multiple uses around a central public realm space. This factor is important to the creation of space and place drawing people into the space while also allowing them to live or work there if they choose. The EAD serves as an entertainment and cultural sector with commercial uses and residential living providing transactions of both social experiences and economic activities.

\subsubsection{Lansdowne Park Redevelopment and the TD Place Stadium}

The city of Ottawa has already undertaken the redevelopment of Lansdowne Park, a sustainable mixed use community characterized by residential, commercial, open space and anchor uses. Fully serviced by Ottawa's OC Transpo bus network, Lansdowne Park is located in the Glebe neighbourhood on the Rideau Canal offering connection to the Rideau Canal Western Pathway. The revitalization of this area began in 2009, with City Council approving the redevel- 
opment in 2010, consisting of a unique public-private partnership between the City of Ottawa, Minto Group, Trinity Development Group, and the Ottawa Sports and Entertainment Group (City of Ottawa, 2015f). Minto Group developed the residential and office portions of the redevelopment while Trinity Development Group developed the commercial retail portion. The Ottawa Sports and Entertainment Group (OSEG) redeveloped the professional football/soccer stadium, including new south side stands and refurbished north side stands. OSEG also completed the refurbishment of the hockey arena located beneath the north side stands.

Due to its proximity to the Rideau Canal, this redevelopment embraced the open space environment by integrating Lansdowne Park with the canal to promote increased active

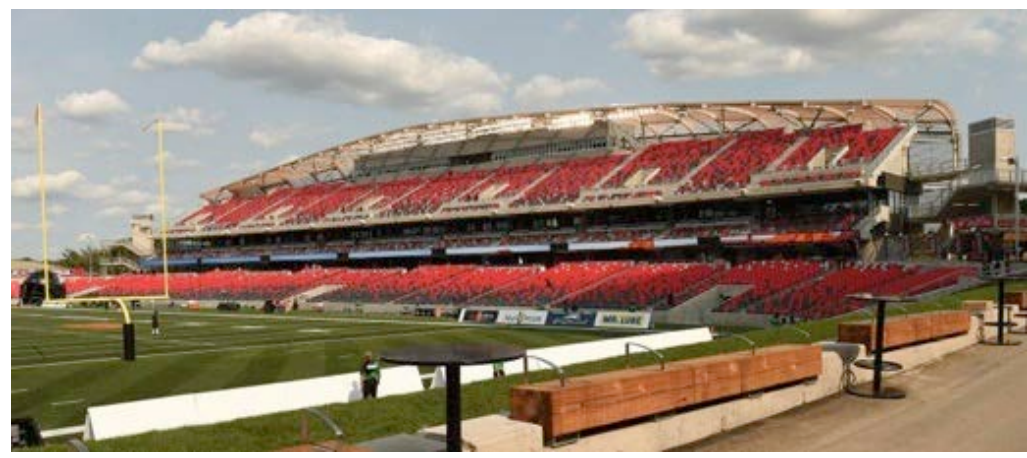
transportation to and within the park and expanding the green space system (City of Ottawa, 2015f). The central idea behind Lansdowne Park was the creation of a live, work, play environment characterized by a central public Photo 17: City of Ottawa (2015e). South stands of TD Place Stadium.

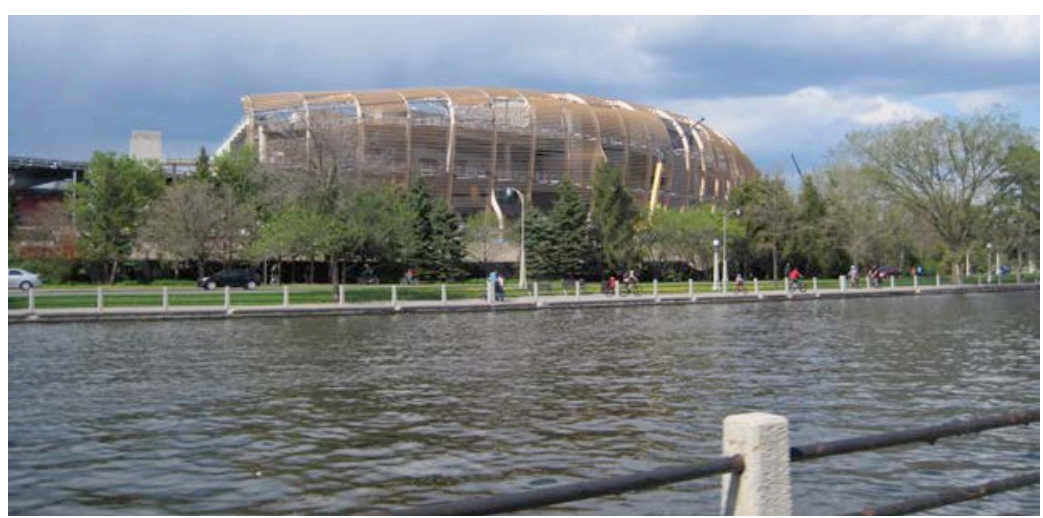

Photo by Sophia Kanavas. Lansdowne Stadium from the Rideau Canal amenity area with complementing residential and office towers as well as commercial retail space. 
In terms of physical design, a combination of high-rise condominiums and stacked townhouse buildings provide 280 residential units, while 360,000 square feet of commercial retail and 100,000 square feet of commercial office amenities are provided in several buildings arranged along a series of new mainstreets. The retail uses at the Shops at Lansdowne bring many new shopping opportunities to the surrounding neighbourhood, and these uses are part of the Glebe Business Improvement Plan for the area (City of Ottawa, 2015e). There are 20 new event spaces compared to the four event spaces before the redevelopment along with five pieces of major and historic art installations. There has also been an increase in bicycle

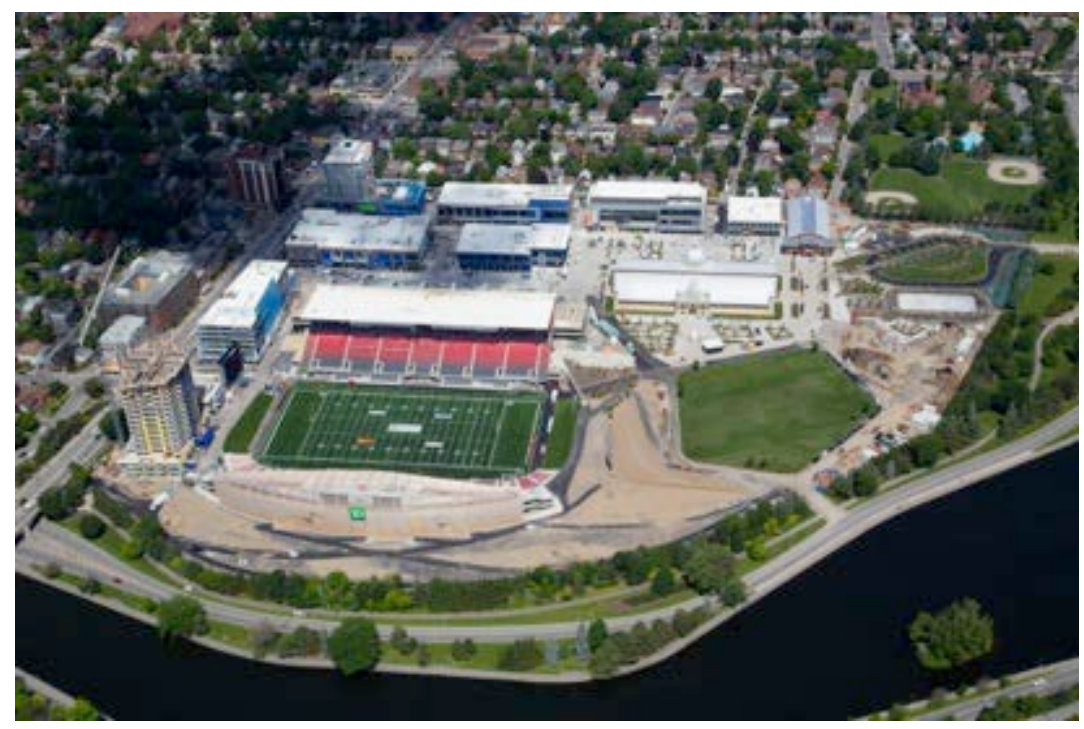
Photo 18: City Ottawa (2015e). Aerial view of Lansdowne Park by the Rideau Canal.

parking spaces from 32 spots to

450 with an optional increase to 1,970 spots on major event days. Approximately 7.2 kilometers of accessible sidewalk and pathway space has been added for pedestrians and cyclists including ramps and access lanes. In addition, one kilometer of bench seating for the public has been incorporated with the addition of seating walls for extra seating (City of Ottawa, 2015f).

As Lansdowne Park is considered a brownfield site it was chosen for a case study because it sets a precedent for development that may be able to occur at LeBreton Flats. Having a local example of a redevelopment strategy headed by the City of Ottawa displays what type of collaboration can occur between the NCC, the City of Ottawa and whichever development group 
is chosen to build the vision of the Flats. Lansdowne Park is also an example of an urban area that combines architectural heritage with a work, live and play environment promoting walkability and social interaction.

\section{Section 5.3 - Summary of Case Precedents}

The case precedents selected here exemplify type of developments that have occurred on other brownfield sites in Canada and internationally. Among these case precedents, there are common themes exhibited by all, although in different ways. Major themes included: trail connection/transit connectivity; anchor use through institutional or event centres; mixed use buildings providing residential and commercial space; and varying forms of public realm through the provision of town squares, parks, and promenades and main streets. In all cases, the strongest theme is that of the high quality public realm. All sites focused on creating environments that encourage use of public and common spaces, such as town squares, parks, and beautiful streetscapes or waterfront/dockland promenades. All of these areas are considered places of transaction and assembly where people gather. Although it is not understood how successful these sites may be just yet, literature tells us that successful urban places involve complex transactions (Montgomery, 1998). These transactions consist not only of economic and monetary forms, but also of social and cultural forms where individuals may interact and go about their daily business (Montgomery, 1998). Such spaces are part of the collective interest as they contribute to the vitality of urban spaces allowing interaction to occur between people and places. 


\section{Chapter 6: Discussion and Recommendations}

Prior to proposing specific recommendations, it is important to note that the City of Ottawa has its own design concepts citing six objectives, which contain 24 themes, as to how good urban design can be applied in the city. However, the City of Ottawa warns that the objectives should only be applied after 'careful contextual consideration' (City of Ottawa 2015g). The six objectives are as follows with example of some of the themes:

1) Create Unique Communities: through the preservation of views and vistas, public art installations, and a mix of building facades;

2) Promote Quality Development: by attention to decorative detail, maintenance of spaces, inspiring architecture and site design;

3) Enhance Safety and Accessibility: through connected and convenient physical environments, natural surveillance of public places and spaces, way finding and strategic lighting;

4) Respect Established Character: complimenting established themes with compatible architecture, community landmarks, cultural landscapes, unique landforms;

5) Incorporate adaptability and diversity: mixed use communities, adaptive reuse and innovation; and

6) Protect Natural Systems: by compact development, resource protection, green development, and green infrastructure (City of Ottawa, 2015g).

\section{Recommendation 1: Compact, Mixed Land Use Development}

Oftentimes large parcels of land may be taken and developed into commercial areas such as power centres or into large residential sections in urban areas. A requirement for any development in LeBreton Flats must display compact, mixed-uses with commercial and residential components. This recommendation is fitting given the existing land use around the site is currently predominantly residential to the south with open space to the west and north of the site and downtown Ottawa to the east. It is also a function of sustainable urban design accompanied by sustainable transport with the future Pimisi Station for the LRT. Mixed land use building should display a diversity of building and housing types as seen in the West Don Lands and the Edmonton Arena District. A compact built environment leads to efficient land use by increasing the 
density in an area allowing people to access facilities and amenities close to where they live (Jabareen, 2006). This is further supported by the NCC's vision for the site to incorporate residential as well as commercial office space opportunities (NCC, 2014c).

Integrating mixed use development and walkable compact communities calls for the implementation of commercial retail and office space to be located on ground level floors of any buildings that are erected in LeBreton Flats. This is backed by the 'eyes on the street' concept proposed by Jane Jacobs and will encourage social and economic interaction.

Due to the built form in the surrounding neighbourhoods around LeBreton Flats, it is recommended that development should incorporate a mixture of building heights in order to add diversity to the landscape of Ottawa. Building a homogenous neighbourhood with the same building height will not provide an architectural appeal nor will it fit into the surrounding area. To the south of the site are mid-rise buildings and to the east and west there are taller apartment and condominium towers. Therefore, LeBreton Flats should incorporate a mix of height in order to fit in with the surrounding area. According to policies set out in 1.11.4.4 c) of the Official Plan, Preston and Booth Streets are to have building heights between 8 and 10 storeys. Albert/Wellington are to have building heights of 6 storeys in order to maintain and respect the character and height of the adjacent West Centretown buildings (City of Ottawa, 2014). Further, these heights can be controlled and maximized by using step backs at the fourth or sixth floors in relation to the angular plane of the street.

The height increase will also provide an increased density in the new development, which will be further supported by the LRT system. However, a diversity of building height shall not be built in the View Control Plane set out by the City of Ottawa from Viewpoint 16 (City of Ottawa, 2014). 


\section{Recommendation 2: Anchor/Institutional Use}

In its Request for Qualifications, the NCC has asked for an anchor or institutional use to act as the core of the development in LeBreton Flats. As seen from the case precedents, an anchor institution can take many forms ranging from a cultural centre to a sports stadium or event arena. Given that the Canadian War Museum is located to the north of the site, and in the future the Holocaust Museum will also be sited at the northeast corner of the Flats adjacent to the land ready for development, the Museum of Science and Technology could relocate to the area to create a pearl of museums in the area. However, to diversify use in the area, a sports arena to house the Ottawa Senators would be feasible, as would an aquarium or performing arts centre to house concerts and other cultural events. A performing arts centre could also be used during Ottawa's Bluesfest, which held outside in LeBreton Park, south of the Canadian War Museum, every July. These types of uses and facilities act as "special activity generators" within districts, drawing in visitors to the area further anchoring redevelopment (Robertson, 1995). Additionally, policy for the area suggests the following permitted uses on LeBreton Flats:

"City Council shall permit a broad range of uses including residential, retail, office, entertainment, cultural, institutional and recreational uses within mixed use areas abutting arterial roads to generate all-day and year-round activity, and serve the needs of the community; and, in this regard, the primary uses shall be office or residential uses." (City of Ottawa, 2014; S. 1.11.3.3 Mixed Use Area, Permitted Uses a.)

The anchor use does not only have to contain one type of use within the building. For example, the adaptive reuse of Maple Leaf Gardens into Ryerson University's Mattamy Athletics Centre and flagship Loblaws store along with other retail stores and a medical centre demonstrates that the anchor building can also contain multiple uses. The Edmonton Arena District is supporting Rogers Place as the anchor institution with a Community Rink attached to the building to service the surrounding residential uses. A multifunctional anchor use would also contrib- 
ute to mixed land use on one site, while also functioning as a landmark for LeBreton Flats, further enhancing the imageability of the area.

\section{Recommendation 3: Walkable Neighbourhoods with Integrated Public Transit}

Emphasizing compact built form through design provides walkable city blocks and human scale (Montgomery, 1998; Jabareen 2006). Proximity to amenities allows people to walk to work or to a local store. This combination of compactness and mixed-use environment in an urban area means that people are more likely to walk, use transit and cycle (Paehlke, 2004). Given that there is an existing trail system in place around the Flats, integrating a walkable neighbourhood will be able to maximize existing infrastructure.

In regards to design, walkability and transit provide connectivity and ease of movement by allowing people from inside the area to navigate outwards and visitors to find their way into the heart of the area. Physical design guidelines through traffic calming can encourage walkability. Building streets on a grid will match the form of the overall City of Ottawa and short blocks of 240 feet or less requires more intersections further slowing

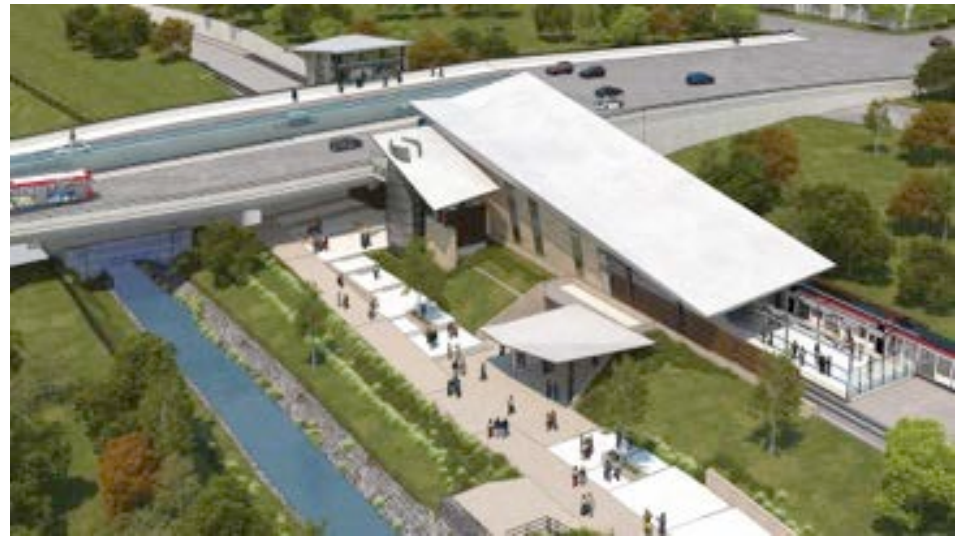

Photo 19: City of Ottawa (2015). Bird's eye rendering of Pimisi Station at LeBreton Flats for Confederation Line. down traffic (Sucher, 2003). Further dedicated pedestrian areas, such as nearby Sparks Street, breaks up the grid and disrupts speedy traffic through urban areas allowing for a mixture of people and cars (Sucher, 2003). 


\section{Recommendation 4: Public Realm Dedication, Access to Open Green Space and Water- front}

A primary recommendation is developing LeBreton Flats such that it blends and connects to the Trans-Canada Trail and other pedestrian and cycling routes, as well LeBreton Flats Park just north of the site. Site analysis shows that there is already a well-developed trail system in place in order to access the waterfront. Therefore it is imperative that the area be made to be conducing to cyclists and pedestrians who wish to access the waters edge. Well-paved, accessible trails lined with trees and flowerbeds contribute to the public realm and the creation of place as well as functioning as a transportation route for pedestrians and cyclists. The northern part of the parcel along the Sir John A. MacDonald Parkway should be dedicated as park space in order to connect with the wider green space system. Additionally, the View Protection under policy 1.11.4.4 d) ii) under the City's Central Area Secondary Policy Plan requires that the view of the downtown core be protected. Therefore nothing should be built in this area in order to preserve the view of the Parliament and other National Symbols from Viewpoint 16 (see appendix policy 1.11.4.4.d.i.) (City of Ottawa, 2014). This is further aided by LeBreton policy that suggests generous setbacks on arterial roads such as Sir John A. MacDonald Parkway (City of Ottawa, 2014).

There should also be the development of a public square, park or centre to act as the art of the Flats and lead the way to the anchor use. A combination of a public space and the anchor use can contribute to place making in a semi public-private space by creating an area where people can gather before and after sports events further encouraging social interaction and diversity.

\section{Recommendation 5: Architectural Design Excellence with Green Design and Parking}

Sustainability is an important part of brownfield redevelopment by using land efficiently and in an environmentally acceptable manner given the previous land use. Therefore this recommendation encourages architectural design excellence through innovative architecture that 
provides a sense of place and visual communication with the incorporation of green building design such as a LEED designation and green development through permeable site surfaces, green roofs and roof top gardens and solar panels (City of Ottawa, 2015c). LEED designation would ensure that any buildings constructed would be made with recycled, low maintenance materials and incorporate water and energy reducing specifications. Creating a LEED neighbourhood or district would ensure that LeBreton Flats is a world-class example of sustainable brownfield redevelopment.

Parking should be provided but be limited to street curb parking in order to enhance the public realm through the addition of trees to control water volume and flow, increase the permeability of the ground, and minimize storm water run off (Metro Portland, 2002). Discouraging the use of large parking lots by placing them underground can go a long way to providing more green space and public amenity areas in which people can enjoy rather than looking out over parking lots. In addition, since the site will be fully serviced by light rail transit it could be argued and proposed by developers that parking be taken out of any development requirements to support more sustainable transportation options, such as transit and cycling. This may be done by cash-in-lieu to support public realm such as a public square or public library.

For lots that must be placed at surface level, parking areas should be broken into small sections with landscaping in between, including flowers and trees as well as low walls ensuring the area can be monitored but is aesthetically pleasing, blending in with surrounding architecture (Tyler and Ward, 2011). 


\section{Chapter 7: Conclusion}

LeBreton Flats is a unique opportunity for the NCC and the City of Ottawa to develop a mixed-use community that will provide cultural and open spaces, public amenities that will make use of the current vacant land. Brownfield literature has shown that remediating contaminated land is good for the environment, the economy and for the public. Reusing such land is a way to combat sprawl and promote the intensification of downtown urban areas.

Urban designers have shown that design is more than just the physical aspects of the city: design must include mental elements, which help people navigate their way around their urban communities. It is the way in which individuals understand their city and design affects how safe people feel on a street or in park. Additionally, design at the street level requires certain factors that help in the creation of place, such as street, wide sidewalks and architectural style. Certain design conditions must also be met to provide multifunctional neighbourhoods that are diverse, lively and liveable such as the density of people and mix of uses, short blocks, sustainable transport, public realm dedication and development intensity.

Regarding LeBreton Flats, supportive policies at federal, provincial, and municipal levels advocate for the intensification of downtown and the redevelopment of brownfields as a public and economic benefit. Further, as demonstrated by the case precedents provided, the use of an anchor institution or landform is not an unusual practice for brownfield or post-industrial redevelopments. Anchor uses may act as catalysts to redevelop former brownfield land due to the large capital costs and investment sometimes undertaken by developers. These uses are often viewed as the heart of a redevelopment with other land uses around an institution to frame a development. However, anchor uses are just one element of a multifaceted project when designing large areas of land. The use must also be accompanied by sustainable transit to attract people to 
the site and calm traffic in the local area. Public realm dedication through public squares, open spaces and trail connections allows people to flow through the site and enjoy different aspects of the development if they so choose.

Overall, LeBreton Flats has a promising future in Ottawa as long as the NCC, the City of Ottawa and the chosen proponent work together to create a new community that provides a new sense of pride to the Nations Capital. 


\section{Appendix:}

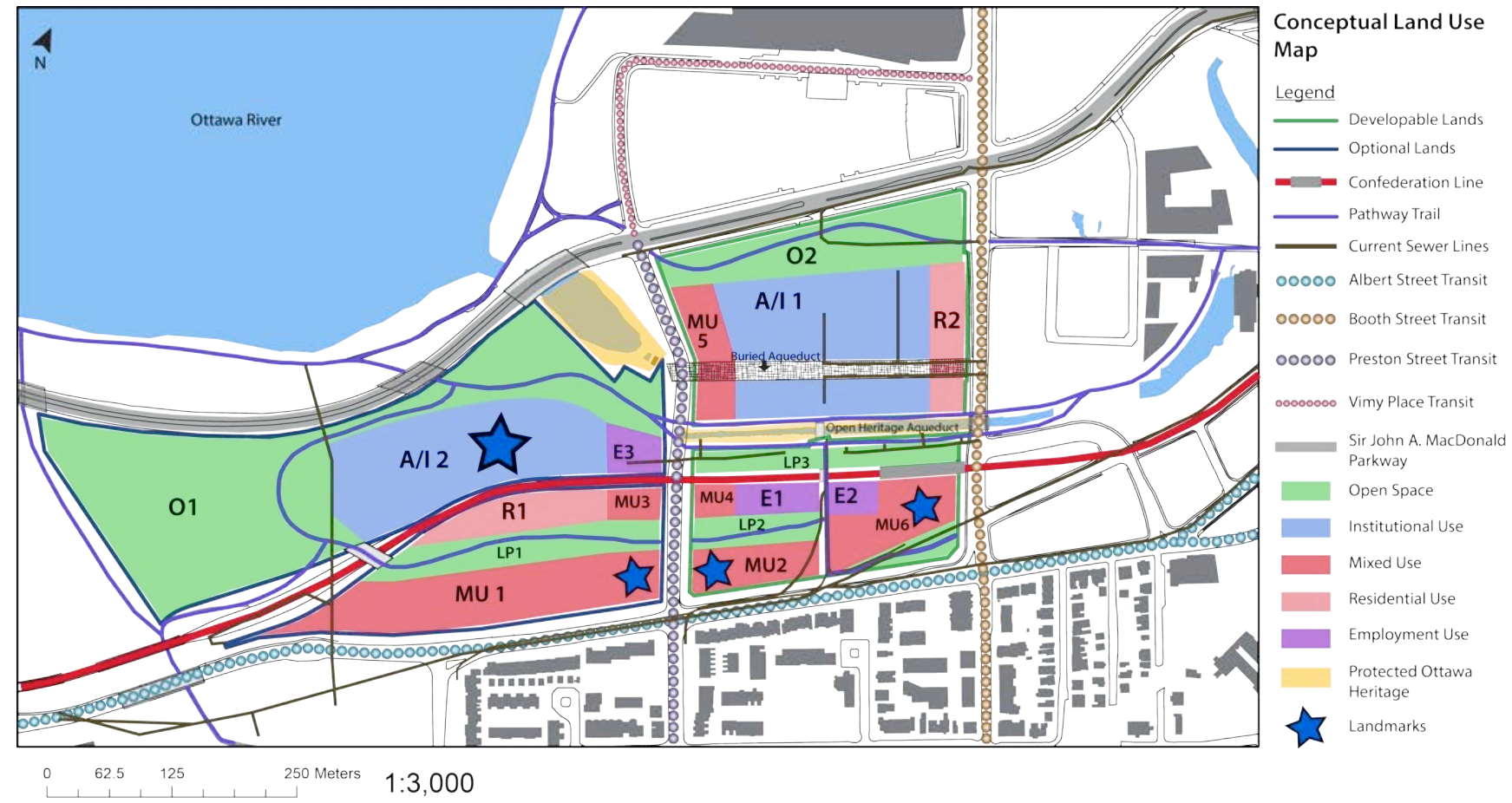

Figure 5: Conceptual land use map for LeBreton Flats

*not to scale due to formatting.

$\mathrm{O} 1$ and 2: Open space, $\mathrm{O} 2$ is on the parkway because of the view protection policies in LeBreton Flats 1.11 of the Official Plan.

A/I 1 and 2: Anchor/institutional uses for both sites. The star on A/I 2 is designated as a large landmark for the site. A/I 1 would be a smaller anchor, such as a community centre or public library due to the sewer servicing on the site by the City of Ottawa and the buried aqueduct, which complicates construction. This area could also feature a linear park to protect the aqueduct.

LP1, 2 and 3: Linear parks to connect the areas and provide green space to residents and employees.

MU 1, 2, 3, 4, 5, and 6: Mixed-use buildings characterized by ground level commercial uses, residential (apartment, condos, affordable housing) and/or office space. All with their perspective buildings heights as set out in 1.11.4.4 Urban Design c).

E 1, 2 and 3: strict employment use. Office towers for government use. This could also be additional NCC offices or commercial headquarters for other businesses.

R1 and 2: strict residential uses characterized by mid-rise towers (apartment, condos, and affordable housing). 
City of Ottawa. (2014). 1.11 LeBreton Flats. Official Plan. Retrieved from:

http://ottawa.ca/en/official-plan-0/10-central-area/111-lebreton-flats

1.11 - LeBreton Flats

(Reference may be made to the report entitled "The LeBreton Flats Plan incorporating Official Plan Amendments" prepared by the National Capital Commission, January 1997. This report contains extensive background information concerning LeBreton Flats.) (Subject to Amendment 143, October 8, 2014]

\subsubsection{Vision [Subject to Amendment 143, October 8, 2014] Unique Site}

LeBreton Flats is a unique site, critical to the future of the heart of the Nation's Capital and the Central Area of the City of Ottawa. LeBreton Flats has a destiny, other than as idle lands, and has the potential to support a vibrant community once again.

People-Place

The Vision is to make LeBreton Flats a people-place for the next century; to challenge the developers and decision makers of the future to create an urbane community within the Ottawa downtown where people can live, work, socialize and play. This community will be one of mixed uses, surrounded by open spaces. It will consist of compact neighbourhoods, linked together and to the wider open space network by pathways and pedestrian-friendly streets. The entire area will be supported by highly accessible public transit, to reduce reliance on the automobile.

\section{Mixed Uses}

LeBreton Flats will mean residential intensification in the Central Area and the introduction of new community-based employment opportunities. Mixed use will be a priority, in achieving a balance of jobs and housing and more efficient use of valuable urban land and infrastructure.

Housing types, sizes and costs will respond to current and upcoming demographic shifts, and offer new opportunities for high quality design at medium to high densities within the Central Area. It will "reclaim" an orphaned site, through ensuring that remediation is undertaken as the site is developed.

National Capital Role

The role of Ottawa as the National Capital will be enhanced by the future LeBreton Flats. One of the last waterfront pieces of real estate in the downtown area will be retained in public hands as open space, with an emphasis on public access, and cultural and office uses of national and capital significance. A "LeBreton Common" will be provided as a major gathering place and stage for events, filling a critical gap in the current system of programmable open spaces in the Capital.

Blueprint for $21^{\text {st }}$ Century

The LeBreton Flats plan represents a blueprint for the 21 st century, which has the ability to satisfy many objectives through its diversity, balance and orientation. 


\subsubsection{Objectives}

a. To provide an extension to the Central Area, with a diverse range of uses and activities, where people can live, work, socialize and play.

b. To create an opportunity to increase the National Capital presence in the Central Area, with development that will attract visitors to Ottawa.

c. To promote compact development and encourage the efficient use of land in proximity to the LeBreton Flats transitway station.

d. To provide an opportunity to substantially increase the number of dwelling units in the Central Area, with a range of housing options.

e. To promote increased employment opportunities in the Central Area.

f. To promote linkages with the adjacent areas and encourage the use of LeBreton Flats by the existing community.

g. To ensure that development is compatible with the adjacent areas.

h. To enhance the unique attributes of the site, such as the riverfront and the aqueduct.

i. To encourage public use and accessibility of the Greenway System.

j. To protect and integrate the designated heritage features such as the aqueduct, its bridges and the Pumping Station, in a sensitive manner.

k. To ensure that infrastructure improvements are identified and undertaken.

1. To ensure that the area meets the applicable soil and groundwater remediation standards.

m. To ensure that development proceeds in an orderly and efficient manner.

\subsubsection{Land Use Policies}

The following policies apply to the land use designations shown on Schedule Q - LeBreton Flats Land Use. The land use categories include: Cultural/Office; Greenway System - Waterway Corridor, Major Open Space, Linkage; Mixed Use; and, Residential 


\subsubsection{Cultural/Office Area \\ Publicly-Oriented Uses}

a. City Council shall support and encourage the development of publicly-oriented uses in the northern section of LeBreton Flats, to serve as a western anchor for Confederation Boulevard and the Parliamentary Precinct.

b. City Council shall permit uses such as museums, art galleries and offices, and shall encourage public access, at least within the ground floors of buildings.

c. City Council shall permit at-grade supporting uses such as retail, entertainment and restaurant venues, to promote this as a lively and attractive people-place during the days and evenings.

d. City Council shall encourage and support the development of new nationally significant non-governmental and governmental uses, and in the expansion of the range of tourist attractions.

Generous Setbacks

e. City Council shall ensure that a generous setback is provided between the Waterway Corridor Area and buildings north of the proposed "LeBreton Common", in order to increase the amount of open space between buildings and the Ottawa River; and, shall encourage this setback area to be developed as publicly-accessible outdoor space associated with those buildings.

\subsubsection{Greenway System}

Orientation

a. City Council shall ensure that the Greenway System provides for public access to the Ottawa River, protection of significant natural areas, provision of municipal and federal park spaces, internal pedestrian/cycle linkages, and connections with the adjacent Greenway System; and in this regard shall support the provision of approximately 40 percent of LeBreton Flats as open space lands.

City Council recognizes that the "Greenway - Major Open Space" designation north of Scott Street and west of the proposed municipal park will remain as vacant land until its future use and remediation requirements are determined and that an official plan amendment may at some time be forthcoming to permit this land to be developed.

Waterway Corridor

b. City Council shall ensure that the Waterway Corridor lands provide a variable width of parkland of at least 40 metres, between the edge of the Ottawa River and the Cultural/Office area, to facilitate public access to the riverfront in an open space environment. 
c. City Council shall require that a Landscaping/Habitat Restoration Plan be prepared to the satisfaction of the City of Ottawa, prior to the development of the Cultural/Office lands, and in conjunction with the proposed removal of the Ottawa River Parkway.

Major Open Spaces

e. City Council shall encourage and support the use of the Major Open Space lands, identified as "LeBreton Common" on Schedule Q, for the staging of national, regional and local festivals and special events, and as a park area for ceremonial and leisure activities.

f. City Council shall encourage the planning and programming of the "LeBreton Common" to address the mitigation of potential negative impacts on the adjacent community; and, shall permit only park use in this regard.

g. City Council shall ensure that adequate community recreational uses are provided through zoning and the development of a proposed municipal park of approximately 2.5 hectares, as shown on Schedule Q.

h. The City of Ottawa shall undertake the planning and design of the proposed municipal park.

i. City Council shall require that the municipal park be dedicated and developed within one year of the registration of a plan of subdivision, or the approval of a site plan control application for any lands adjacent to the park.

Natural Features

j. City Council shall require the retention of the major wooded areas and natural features within Linkage lands in the vicinity of the Fleet Street Pumping Station and the tailrace.

Linkage Lands

k. City Council shall require that a minimum of 5 metres of open space is provided between the proposed fence line along the aqueduct and adjacent properties, to provide pedestrian/cycle paths for access to the proposed municipal park and to the rest of the Central Area.

1. City Council shall encourage the National Capital Commission to develop the aqueduct area as parkland, taking into consideration its heritage, and landscape/habitat values, in the context of its importance to the vitality and attractiveness of LeBreton. 
m. City Council shall investigate using the aqueduct inlet water area as a leisure resource, while recognizing its function as the inlet to the operating underground conduit which provides water power to the Fleet Street Pumping Station.

n. City Council shall ensure that the existing aqueduct bridges, where possible, provide pathway connections over the aqueduct

o. City Council shall ensure that any potential negative impact on the aqueduct inlet and tailrace areas resulting from the construction of new bridges associated with the proposed "LeBreton Boulevard" is minimized through an Environmental Assessment process.

p. City Council shall encourage the retention of the kayak training course in the tailrace.

q. City Council shall require that applications for site plan approval for developments abutting the aqueduct tailrace are supported by geotechnical assessments to evaluate slope stability and development setbacks.

r. The City of Ottawa shall undertake a recreational and cultural needs study for Planning District 3, which will identify those requirements that should be included in the development of the LeBreton Flats community.

Thomson-Perkins Mill

s. City Council shall permit commercial uses in the Thomson-Perkins Mill heritage building.

1.11.3.3 Mixed Use Area

Permitted Uses

a. City Council shall permit a broad range of uses including residential, retail, office, entertainment, cultural, institutional and recreational uses within mixed use areas abutting arterial roads to generate all-day and year-round activity, and serve the needs of the community; and, in this regard, the primary uses shall be office or residential uses.

Transit Use

b. City Council shall permit high density/profile office and/or residential uses above the ground floor of buildings along Booth Street, south of the proposed "LeBreton Boulevard", to encourage the use of transit facilities. 
Use Integration

c. City Council shall support the integration of residential and commercial and other uses within the same blocks and/or the same buildings.

\section{Pedestrian-Oriented Uses}

d. City Council shall require that Booth Street provides a variety of small-scale, continuous, ground floor pedestrian-oriented uses, such as retail, restaurant and personal service uses, in creating a "Main Street" focus to serve the new community and visitors to the area.

e. City Council shall permit a variety of ground-floor, small-scale retail, cultural, restaurant and entertainment uses, below residential uses along the north side of the aqueduct, to enhance public activity along this part of the aqueduct; and, in this regard, shall encourage the integration of the non-built area of these properties with the adjacent aqueduct Linkage lands.

f. City Council shall permit limited retail development in other areas to provide for the immediate needs and convenience of residents, workers and visitors, while not detracting from the "Main Street" focus along Booth Street.

g. City Council shall require that predominately residential development be provided along local residential streets with commercial development focused along Booth Street.

\subsubsection{Residential Area}

a. City Council shall support the provision of a range of housing forms in medium to high profile buildings of a density appropriate to the downtown area, generally ranging from stacked townhouses to apartment buildings, to make effective use of the infrastructure, services and facilities within the inner-city area.

\section{Affordability and Accessibility}

b. In support of the City Council's commitment to achieve affordable housing within the Central Area, City Council shall require;

i. That the amount of land to be set aside through the subdivision approval process shall be sufficient to allow $25 \%$ of the total housing stock within LeBreton Flats to be affordable Housing to the Action Ottawa criteria, or to the new Official Plan and proposed Municipal Housing Statement when approved;

ii. That the City work with the National Capital Commission to facilitate partnerships between non-profit housing providers and commercial developers to explore options for providing affordable housing above ground floor commercial developments, to meet the $25 \%$ target; 
iii. That should affordable housing targets not be met prior to $50 \%$ of the building permits being issued, City Council will require that the subdivision agreement provide for the City to be given by the National Capital Commission, the first right to acquire the lands for affordable housing.

iv. That Council request the National Capital Commission to explore options for facilitating affordable housing by providing long term leases for one (\$1.00) dollar to developers willing to build and maintain affordable housing. [Amendment \#2, September 3, 2003]

Density and Profile

c. City Council shall permit high density/profile residential buildings immediately south of the proposed municipal park, and along "LeBreton Boulevard", which will function as an arterial road.

Small-Scale Open Spaces

d. City Council shall require that the local open space and recreation needs that are not met by the proposed municipal park, such as small play areas for children, be provided within residential areas through the development application review process.

Orientation

e. City Council shall encourage housing development to be oriented to the local streets, in order to promote community interaction, safety and security.

Childcare Facilities

f. Through the subdivision and site plan control processes, City Council shall investigate with property owners, options for providing childcare facilities in residential developments. These facilities should be provided at a rate of 9.3 square metres per child for interior space and 5.6 square metres per child for exterior space. Each facility constructed should be for a minimum of 50 children. [Amendment \#2, September 3, 2003]

1.11.4 General Policies

The following general policies shall apply to LeBreton Flats.

1.11.4.1 Transportation

Transit Way and Station

a. City Council shall encourage the construction of the proposed new transitway and station, prior to the start of development, to avoid negative impacts on the new community during construction; and, shall encourage a high level of pedestrian/cycle access to the transit station and the provision of cycle storage facilities. 
Parkway Relocation and LeBreton Boulevard

b. City Council shall support the relocation of the Ottawa River Parkway within LeBreton Flats, in order to ensure that the riverfront area is opened up to the public. With regard to LeBreton Boulevard, the National Capital Commission will ensure the required environmental assessment and functional design will address the impacts that the alignment will have on building heights and views in accordance with the City of Ottawa Official Plan.

Traffic Impact Studies

c. City Council shall require that traffic impact studies be undertaken prior to the approval of applications for development, to ensure that site-generated traffic can be adequately accommodated and/or that measures are carried out to meet identified deficiencies, to the satisfaction of the City of Ottawa and the Regional Municipality of Ottawa-Carleton.

Noise Studies

d. City Council shall require that noise studies be undertaken to the satisfaction of the City of Ottawa for development adjacent to the proposed transitway and station, and along arterial roads, and that appropriate mitigation measures are undertaken to address potential impacts.

Traffic Calming

e. City Council shall require that traffic calming be considered in the design of local roads serving the residential areas, with a focus on minimizing potential shortcutting by through traffic, and as a means of improving livability and pedestrian and cycle safety, through Urban Design Guidelines, as set out in 1.11.4.4 a) below.

Alternate Development Standards

f. City Council shall require that Alternate Development Standards be considered in determining the appropriate rights-of-way and adequate pedestrian, cycle and roadway facilities, through Urban Design Guidelines, as set out in 1.11.4.4 a) below.

Pedestrian/ Cycle Path System

g. City Council shall encourage the incorporation of a continuous pedestrian/cycle path system within the Greenway, to encourage non-automobile movement; and, shall ensure its integration with facilities in the rights-of-way, and linkage with pathways outside LeBreton Flats. 
h. City Council shall encourage publicly-accessible pathways to the waterfront area through the northern Cultural/Office lands, and the "LeBreton Common".

i. City Council shall support the provision of commuter cycling lanes along the proposed arterial roads.

j. $\quad$ City Council shall require an at-grade connection to Booth Street from the proposed pedestrian/cycle path along Ottawa Street to the west and the Linkage lands to the east.

k. City Council shall support the retention of the existing Heritage Designated aqueduct bridges as pedestrian/cycle connections across the aqueduct, in order to encourage safe north/south movement.

1. City Council shall support the retention of the Heritage Designated Pooley's Bridge as a pedestrian/cycle connection.

m. City Council shall support the provision of a pedestrian/cycle link under the Preston Street extension at the aqueduct, for access to the proposed municipal park.

Parking

n. City Council shall support shared parking facilities in mixed use developments, to encourage the efficient use of lands and the integration of uses; and, shall consider reduced parking requirements for developments within walking distance of the proposed transit station, to encourage the use of public transit; and, shall discourage surface parking facilities, to minimize the negative impact of such facilities.

Tour Bus Parking

o. City Council shall support the continuation of tour bus parking in LeBreton Flats in cooperation with the National Capital Commission, while ensuring that potential noise, visual and traffic impacts are minimized, and the development of the LeBreton Flats Character Area is not compromised.

p. City Council shall encourage the provision of adequate automobile and tour bus parking to serve the proposed LeBreton Common through such means as:

i. $\quad$ shared use of parking facilities associated with uses within the Cultural/Office lands on LeBreton; and

ii. utilizing parking facilities in the adjacent non-residential areas such as the Core Area and Parliamentary Precinct. 
Community Linkage

q. City Council shall encourage the provision of adequate pedestrian and cycle connections across Scott/Wellington/Albert Street, to encourage the safe movement of people between LeBreton Flats and the existing community.

Transit Servicing Plan

r. City Council shall, as a priority, develop in consultation with the National Capital Commission, a transit servicing plan for LeBreton Flats that will be integrated with the City's transit system and shall require the provision of infrastructure and facilities such as but not limited to pedestrian paths and connections, transit stops, transit priority lanes along new roads, and Transportation Demand Management plans, to support the transit service plan through the development approvals process. [Amendment \#2, September 3, 2003]

\section{Roadway Concept Plan}

s. City Council shall require that the National Capital Commission develop a comprehensive roadway concept plan for all the roads to be developed and/or improved within LeBreton Flats. This concept plan will identify roadway cross sections that respond to policies in the Secondary Plan, the location of below and above grade services and will be subject to acceptance by the City and Utility Agencies. City Council will require that the accepted concept plan be used to define/detail conditions related to the construction of roads through subdivision and road opening approvals. [Amendment \#2, September 3, 2003]

\subsubsection{Environment}

Soil and Ground Water Contamination

a. City Council shall require environmental site assessment and restoration within the spirit of the Ministry of the Environment Guidelines for Use of Contaminated Sites in Ontario 1996 (revised February 1997), or other federal, provincial, or municipal regulations, as applicable, in effect at the time of development. In this regard, a Phase II Environmental Site Assessment shall be completed within the spirit of the Guidelines, prior to the final approval of a subdivision, severance or site plan control application for the area of such application. It is acknowledged that both City Council and the Ministry of the Environment have accepted certain Phase I and Phase II Environmental Site Assessments completed prior to the release of this guideline, towards fulfilling the spirit of the Guideline. [Amendment \#2, September 3, 2003]

Site Remediation Plans

b. City Council shall require that site-specific remediation plans and commitments to site restoration be undertaken prior to the final approval of a subdivision, sever- 
ance or site plan application for the area of such application within LeBreton Flats; an Integrated Environmental Report will be required prior to the final approval of such applications.

Methane Gas Monitoring

c. City Council shall require further methane gas monitoring of the Nepean Bay landfill site, to assess the impact on the feasibility and soil management requirements for the proposed municipal park lands, as part of the Phase 2 ESA, as set out in Policy 1.11.4.2 a) above.

d. City Council shall require methane gas monitoring of any development within 30 metres of the Nepean Bay landfill.

Urban Forest

e. City Council shall encourage the augmentation of the urban forest throughout the site in the review of applications for site-specific developments.

1.11.4.3 Infrastructure

Master Servicing Plan

a. City Council shall require that a Master Servicing Plan, to address existing and proposed utilities and piped services, be prepared to the satisfaction of the City of Ottawa, and appropriate utility companies, prior to the submission of the initial development application; and, that this Plan provide details on the anticipated timing, funding, construction, maintenance and ownership responsibilities, in the context of the phasing of development. Should changes occur to the assumptions contained in this Plan as development takes place, the Plan shall be adjusted accordingly.

Underground Services

b. City Council shall require that electrical, telephone and television cables be placed underground.

\section{Stormwater Management}

c. City Council shall require that Stormwater Site Management Plans be submitted prior to the final approval of a subdivision, severance or site plan application, to the satisfaction of the City of Ottawa. These plans shall be consistent with the overall Stormwater Management Feasibility Plan and, where phased development is proposed, will identify any phasing for the implementation of the stormwater site management plan and any necessary interim stormwater management measures. 


\subsubsection{Urban Design \\ Urban Design Guidelines}

a. City Council shall require that a set of broad Urban Design Guidelines for the entire LeBreton Flats area be prepared, in order to assist in the design of development, rights-of-way and open spaces, and their interrelationships, in an integrated and cohesive manner, prior to the initial submission of an application for development approval; and, that such urban design guidelines shall consider Alternate Design Standards and Traffic Calming.

Wind Testing

b. City Council shall require wind testing of medium and high profile development proposals to evaluate the impact on streets, open spaces and other pedestrian activity areas and determine mitigation measures, prior to the approval of applications for Site Plan Control Approval.

Building Heights

c. City Council shall require that maximum building profiles be as described generally in the following:

i. up to six storeys for buildings fronting on Scott/ Wellington/Albert Streets to provide for compatibility with the existing community;

ii. up to eight storeys at Preston and Booth Streets along Scott/ Wellington/Albert Streets, to provide for landmark buildings at the southern entrances to LeBreton Flats, and high density development in proximity to the transitway station on Booth Street;

iii. $\quad$ up to ten storeys along Booth Street south of "LeBreton Boulevard", to provide for high density development in proximity to the transitway station on Booth Street;

iv. $\quad$ up to twelve storeys along the "LeBreton Boulevard" arterial road, while ensuring that a high-profile continuous wall of buildings is avoided, and that the policies in the Official Plan for protecting views of the Parliament Buildings and Other National Symbols are respected;

v. up to six storeys in the Cultural/Office Area, north of "LeBreton Boulevard", in recognition of its proximity to the Greenway System, while ensuring that the policies in the Official Plan for protecting views of the Parliament Buildings and Other National Symbols are respected; and

vi. up to six and eight storeys within the majority of the Residential Areas.

vii. To ensure that appropriate scale relationships will be provided along streets where development with a height of 10 stories is permitted on one side of the street and a building height limit of six stories is established along the opposite side of the street as shown on Map 4, City Council shall require that the higher profile development integrate with lower profile development through various techniques as set out in the Urban Design Policies of the Official Plan (Central Area Urban Design Policies set out in 
Chapter 5.0 and the General Urban Design Policies set out in chapter 12.0) to provide for achieving harmonious street environments consistent with the principals set out in the urban design guidelines developed as required by policy 1.11.4.4. [Amendment \#24, May 25, 2005]

View Protection

d. City Council shall ensure that:

i. in the area identified on Ottawa Official Plan, Annex 6 C- LeBreton Flats Foreground View Control Planes extending from Viewpoint 16 as shown on Ottawa Official Plan, Annex 6 A to the eastern limit of LeBreton Flats Character Area as shown on Schedule B - Central Area Character Area and Theme Streets, with the exception of Area "A" identified on Ottawa Official Plan, Annex $6 \mathrm{C}$, no building, part of a building or building roof structure, shall project above the building height limit planes established by the central and lateral foreground view planes defined by geographic coordinates and above sea level elevations on Ottawa Official Plan, Annex 6 $\mathrm{C}$;

ii. building heights in Area "A" on Ottawa Official Plan, Annex $6 \mathrm{C}$ shall not exceed 79.9 metres above sea level;

iii. in the area adjacent to the LeBreton Flats Foreground View Control Planes as shown on Ottawa Official Plan, Annex 6 C, no building, part of a building or building roof structure shall project into the lateral foreground view planes described on Ottawa Official Plan, Annex 6 C;

iv. in the area defined by a view with a viewpoint located in the centre of the proposed LeBreton Boulevard right-of-way immediately west of the intersection of the Booth Street right-of-way, no building, part of building or building roof structure shall be constructed. This protected view, as illustrated on Figure 1, is intended to provide for an unobstructed foreground view panorama extending from the Great Hall of the National Gallery in the north to the northwest corner of the upper terrace of the Garden of the Provinces on the south. 


\section{FIGURE 1}

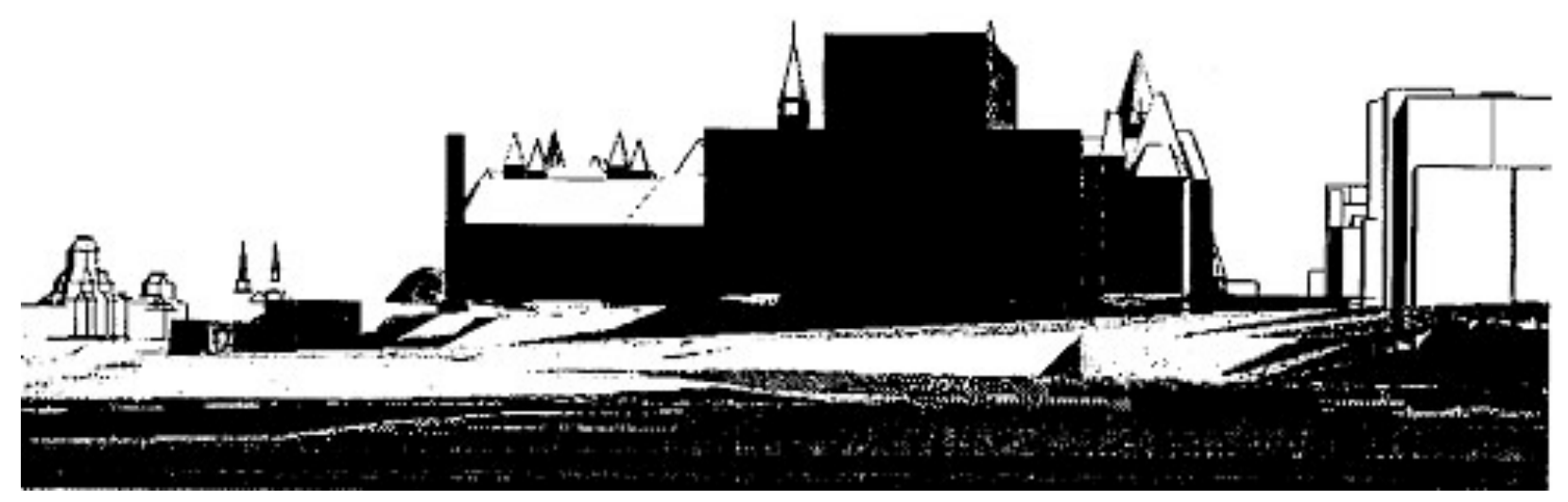

Integration

e. City Council shall encourage the integration of residential, office, and retail uses in mixed use areas in configurations and building forms that allow unique opportunities for creative development.

Special Needs

f. City Council shall ensure that development accommodates the needs of persons with disabilities and other special needs groups.

\subsubsection{Implementation and Interpretation [Subject to Amendment 143, October 8, 2014]}

1.11.5.1 Implementation

Development Preconditions

a. City Council shall require that prior to the submission of the initial application for development within LeBreton Flats, in the form of a Plan of Subdivision, Master Plan, rezoning, severance and/or site plan, the following have been prepared for the entire LeBreton Flats area, to the satisfaction of the City of Ottawa and the National Capital Commission, as appropriate, or other pertinent agencies:

i. $\quad$ Urban Design Guidelines, as set out in Policy 1.11.4.4 a) above;

ii. Master Servicing Plan, as set out in Policy 1.11.4.3 a) above; and

Development Prerequisites

b. City Council shall ensure that the following have been prepared to the satisfaction of the City of Ottawa and the National Capital Commission and other pertinent agencies as appropriate 
i. $\quad$ Traffic Impact Studies as set out in Policy 1.11.4.1c), prior to the final approval of site specific applications for rezoning, subdivision, site plan control or severance;

ii. Phase II Environmental Site Assessment and Contamination studies, as set out in Policy 1.11.4.2a), prior to the final approval of site specific applications for Subdivision, Severance or Site Plan Control;

iii. Site Specific Remediation Plans as set out in Policy 1.11.4.2c), prior to the final approval of site specific applications for subdivision, site plan control approval or severance;

iv. Noise Studies, as set out in Policy 1.11.4.1d), prior to the Final Approval of applications for subdivision, severance or site plan control; and

v. Stormwater Site Management Plan, as set out in Policy 1.11.4.3c), prior to final approval of applications for subdivision, severance or site plan control".

Regular Reporting

c. City Council shall encourage the National Capital Commission to prepare regular reports on environmental management and planning aspects for LeBreton Flats, to inform the public and agencies of progress in this regard.

Street Names

d. City Council shall ensure that streets are named through the normal street naming procedures, with priority given to retaining existing street names and recognizing the history of the area.

1.11.5.2 Implementation Tools

Plans of Subdivision

a. City Council shall encourage the submission of applications for Plans of Subdivision as the preferred means of ensuring the orderly and efficient development of LeBreton Flats; should applications for Plans of Subdivision not be forthcoming, Master Plans shall be undertaken prior to the approval of development applications.

b. City Council shall ensure that Plans of Subdivision and Master Plans are consistent with the Urban Design Guidelines, as set out in Policy 1.11.4.4 a) above.

Holding Zone

c. City Council may utilize a holding (h) symbol in conjunction with any use designation in the Zoning By-law, to defer development of all or part of the LeBreton area, where it is determined that any proposed development is premature or that immediate development is inappropriate. These determinations will be based on the preconditions and prerequisites, as set out in Policy 1.11.4.5 a) and b) above, 
and will be used wherever cost sharing arrangements may be required and/or funding is not committed.

\section{Consents}

d. City Council shall encourage the Committee of Adjustment to ensure that the Plan of Subdivision method is upheld as the primary method of providing lots, to ensure orderly and efficient development.

e. City Council shall encourage the Committee of Adjustment, in reviewing consent applications, to take into account the preconditions and prerequisites of Policy 1.11.4.5 a) and b) above, and the objectives and policies of the LeBreton Flats Character Area.

\subsubsection{Interpretation}

a. City Council shall ensure that interpretation of the LeBreton Flats Character Area has regard to all applicable policies set out in the City of Ottawa Official Plan. 


\section{References:}

AMEC Earth and Environmental. (2011). Remedial Action Plan - Lansdowne Park and Sylvia Holden Commemorative Park. Retrieved from:

http://documents.ottawa.ca/sites/documents.ottawa.ca/files/documents/con06564.pdf

Amekudzi, A., and Fomunung, I. (2004). Integrating brownfields redevelopment with transportation planning. Journal of Urban Planning and Development. 130, 204-212

BenDor, T. K., Metcalf, S. S., and M. Paich. (2011). The Dynamics of Brownfield Redevelopment. Sustainability. 3, 914-936

Beton-Short, L. and Short, J. R. (2008). Cities and Nature. New York, NY: Routledge

Bond, R. (1961). City on the Ottawa. Ottawa, Ontario: Minister of Public Works.

CABE, DETR. (2000). By Design: Urban Design in the Planning System - Towards Better Practice. London: Thomas Telford.

Canada's Capital Core Area Sector Plan. (2005). National Capital Commission. Retrieved from: http://www.ncc-ccn.gc.ca/sites/default/files/pubs/Core-Sector-Report-2005.pdf

Canada Environmental Assessment Agency. (2012). Archived-LeBreton Flats Remediation and Infrastructure Project. Retrieved from: http://www.ceaa.gc.ca/052/details-eng.cfm?pid=63727

Canadian Institute of Planners. (2015). Urban Design. Topics in Planning. Retrieved from: http://cip-icu.ca/Topics-in-Planning/Urban-Design

Childs, M. C. (2008). Storytelling and urban design. Journal of Urbanism: International Re search on Placemaking and Urban Sustainability. 1(2), 173-186

City of Ottawa. (2003). City of Ottawa Official Plan A Component of Ottawa 20/20, the City's Growth Management Strategy. Retrieved from:

http://ottawa.ca/en/official-plan-0/volume-1-official-plan

City of Ottawa. (2010). Brownfields Redevelopment Community Improvement Plan. Ottawa: Ontario. Retrieved from:

City of Ottawa. (2013). Transportation Master Plan. Pp. 1-135. Retrieved from: http://ottawa.ca/en/city-hall/planning-and-development/official-and-masterplans/transportation-master-plan

City of Ottawa. (2014). 1.11 LeBreton Flats. Official Plan. Retrieved from: http://ottawa.ca/en/official-plan-0/10-central-area/111-lebreton-flats

City of Ottawa. (2015a). Official Plan and Master Plans. Retrieved from: http://ottawa.ca/en/city-hall/official-and-master-plans

City of Ottawa. (2015b). Population and households (occupied dwellings) estimates by ward, year end 2012. Retrieved from: http://ttawa.ca/en/city-hall/get-know-yourcity/statistics/population-and-households-occupied-dwellings-estimates-ward

City of Ottawa. (2015c). Protect Natural Systems. Retrieved from: http://ottawa.ca/en/cityhall/planning-and-development/community-plans-and-design-guidelines/design-andplanning-0/ur--9

City of Ottawa. (2015d). The Plan: When will it happen? Retrieved from: http://www.confederationline.ca/en/the-plan/when/

City of Ottawa. (2015e). What's at Lansdowne. Retrieved from: http://ottawa.ca/2/en/residents/parks-and-recreation/recreation-facilities/lansdownepark/whats-at-lansdowne

City of Ottawa (2015f). What we are building. Retrieved from: 
http://ottawa.ca/en/city-hall/planning-and-development/transforming-ottawa/what-weare-building

City of Ottawa. (2015g). The City's Design Objectives. Retrieved from:

http://ottawa.ca/en/city-hall/planning-and-development/community-plans-anddesign-guidelines/design-and-planning-0/ur--4

DePass, M. (2006). Brownfields as a tool for the rejuvenation of land and community. Local Environment. 11(5): 601-606

De Sousa, C. A. (2002). Brownfield redevelopment in Toronto: an examination of past trends and future prospects. Land Use Policy. Vol. 19, pp. 297-309.

De Sousa, C. A. (2006a). Unearthing the benefits of Brownfield to Green Space Projects: An Examination of Project Use and Quality of Life Impacts. Local Environment. 11(5): 577600

De Sousa, C. A. (2006b). Urban Brownfields redevelopment in Canada: the role of local government. The Canadian Geographer. 50(3): 392-407

EAD JV Inc. (2015). Edmonton Arena District. Retrieved from: http://www.ead.ca/

Erickson, B. (2001). The 'armature' and 'fabric' as a model for understanding spatial organization. InM. Roberts and C. Greed (Eds.), Approaching urban design: the design process (pp. 21-38). Harlow, England: Longman/Pearson Education.

Ewing, R., Clemente, O., Neckerman, K. M., Purciel-Hill, M., Quinn, J. W., and Rundle, A. (2013). Measuring urban design: Metrics for livable places. Washington, DC: Island Press

Ewing, R. and Handy, S. (2009). Measuring the Unmeasureable: Urban Design Qualities Related to Walkability. Journal of Urban Design. 14(1), 65-84

Fotenn. (2012). 19 Beechwood Zoning By-Law Amendment Application. Obtained through Minto Group Ottawa.

Greenberg, M., Lowrie, K., Solitare, L., and L. Duncan. (2000). Brownfields, toads, and the struggle for neighbourhood redevelopment - A case study of the state of New Jersey. Urban Affairs Review. 35, 717-733

Heberle, L. and Wernstedt, K. (2006). Understanding brownfields regeneration in the US. Local Environment. 11, 479-497

Hula, R. C. and Bromley-Trujillo, R. (2010). Cleaning Up the Mess: Redevelopment of Urban Brownfields. Economic Development Quarterly. 24 (3): 276-287

Jabareen, Y. R. (2006). Sustainable Urban Forms. Journal of Planning Education and Research. 26, 38-52

Jacobs, A. B. (1993). Great Streets. Cambridge, Massachusetts: MIT Press.

Jacobs, A. B. (1985). Looking at Cities. Cambridge, Massachusetts: Harvard University Press.

Johnson, K. L., Dixson, C. E., \& Tochterman, S. P. (2002). Brownfield redevelopment and transportation planning in the philadelphia region. Institute of Transportation Engineers Journal [H.W. Wilson-AST]. 72(7), 26

LaGro, J. A. (2013). Site Analysis. New York: Wiley \& Sons.

Laitos, J. G., \& Abel, T. H. (2011). The role of brownfields as sites for mixed-use development projects in America and Britain. Denver Journal of International Law and Policy. 40 (1-3), 492

Larice, M. and MacDonald, E. (eds). (2007). The Urban Design Reader. New York: Routledge 
Leigh, N. G. and Coffin, S. L. (2005). Modeling the relationship among brownfields, property values, and community revitalization. Housing Policy Debate. 16, 257 280

Lynch, K. (1960). The Image of the City. Cambridge, Massachusetts: MIT Press.

MacNair, G. E. (2014). Real Property Challenges with Ottawa's largest infrastructure project in recent history. Canadian Property Valuation. 58 (1): pp. 20-23

Metro Portland. (2002). Green Streets. In M. Larice and E. MacDonald (Eds.), "The Urban Design Reader" (pp. 405-427). New York: Routledge

Montgomery, J. (1998). Making a city: Urbanity, vitality and urban design. Journal of Urban Design. 3(1), 93-116.

Moughtin, C., Cuesta, R. Sarris, C., and Signoretta. P. (2003). Urban Design Method and Techniques, $2^{\text {nd }}$ edn. Oxford: Architectural Press.

National Capital Commission. (2014a). Capital Urban Lands Master Plan 2014.

National Capital Commission. (2014b). LeBreton Flats, Past, Present and Future Virtual Exhibit. Flickr. Retrieved from: https://www.flickr.com/photos/ncc-ccn/sets/72157648085014362/show/

National Capital Commission. (2014c). Request for Qualifications Redevelopment of LeBreton Flats (PDF). Government of Canada. Retrieved from "Redeveloping LeBreton Flats" at: http://www.ncc-ccn.gc.ca/sites/default/files/pubs/ncc-lebreton-rfq.pdf

National Capital Commission. (2015a). About the NCC. Retrieved from: http://www.ncc-ccn.gc.ca/about-ncc

National Capital Commission. (2015b). History. LeBreton Flats. Retrieved from: http:/www.ncc-ccn.gc.ca/planning/master-plans/lebreton-flats/history

National Capital Commission. (2015c). Redevelopment of LeBreton Flats. LeBretron Flats. Retrieved from: http://www.ncc-ccn.gc.ca/planning/master-plans/lebretonflats/redevelopment-of-lebreton-flats

National Capital Commission. (2015d). The National Capital Commission invites proponents to develop detailed proposals for LeBreton Flats. Retrieved from: http://www.ncc-ccn.gc.ca/property-management/what-we-manage/news/2015-0218/national-capital-commission-invites-proponents-to

National Round Table on the Environment and the Economy. (2003). 'Cleaning up the Past, building the future' a national Brownfield redevelopment strategy for Canada. Ottawa: Renouf Publishing Co. Ltd.

OC Transpo. (2015). Confederation Line. Retrieved from: http://www.octranspo1.com/routes/o_train_new_stations

Ontario Ministry of Municipal Affairs and Housing (OMMAH). (2014). Provincial Policy State, 2014. Queen's Printer for Ontario. Retrieved from: http://www.mah.gov.on.ca/Page215.aspx

Ontario Ministry of Municipal Affairs and Housing (OMMAH). (2015). The Planning Act? Queen's Printer for Ontario. Retrieved from: http://www.mah.gov.on.ca/Page1760.aspx

Paehlke, R. (2004). Greenville: Applying green principles to buildings and urban planning is a sound long-term investment of public dollars. Alternatives. 30(5): 12-17

Queen's Printer for Ontario. (2014). Provincial Policy Statement. Toronto, Ontario: 
Ministry of Municipal Affairs and Housing.

Relph, E. (1976). On the identity of places. In M. Carmona and S. Tiesdell (Eds.), "Urban Design Reader" (pp. 103-107). Oxford: Architectural Press.

Robertson, K. (1995). Downtown redevelopment strategies in the United States: An end-of-thecentury assessment. Journal of the American Planning Association. 61, 429-437

Robinson, G. (2014). In Line. ReNew Canada - The Infrastructure Magazine. January/February

Ross, A. H. D. (1927). Ottawa Past and Present. Toronto, Ontario: The Mudson Book Co. Limited

Sepe, M. and Pitt, M. (2014). The characters of place in urban design. Urban Design International. 19(3), 215-227

Smith, A. and I. von Krogh Strand. (2011). Oslo's new Opera House: Cultural Flagship regeneration tool or destination icon? European Urban and Regional Studies. 18 (1), 93-110

Sternberg, E. (2000). An Integrative Theory of Urban Design. Journal of American Planning Association. 66(3), 265-278

Sucher, D. (2003). Getting Around. In M. Larice and E. MacDonald (Eds.), "The Urban Design Reader" (pp. 391-404). New York: Routledge

Tyler, N., and Ward, R. M. (2011). Planning and Community Development: A Guide for the $21^{\text {st }}$ Century. New York: W. W. Norton \& Company Inc.

Taylor, J. H. (1986). Ottawa, An Illustrated History. Toronto, Ontario: James Lorimer \& Company.

Urban Design Associates. 2005. West Don Lands Precinct Plan. Toronto, Ontario.

Urban Strategies (2015). London Docklands. Retrieved from: http://www.urbanstrategies.com/project/london-docklands/

WAM Development Group. (2015). Edmonton Arena District. Retrieved from: http://www.wamdevelopment.com/projects/edmonton-arena-district/

Whyte, W. H. (1980). The Social Life of Small Urban Spaces. Washington. D.C.: Conservation Foundation.

\section{Image References}

\section{Chapter 3 Images:}

\section{Photo 4:}

NCC. (2014). Flickr. Retrieved from:

https://www.flickr.com/photos/ncc-ccn/sets/72157647764603437/

\section{Photo 5:}

NCC. (2007). Flickr. Retrieved from:

https://www.flickr.com/photos/ncc-ccn/15391211111/in/set-72157647764603437

\section{Photos 6, 7, and 8}

Cross Roads. 2007. Photos from Collections Canada. Retrieved from:

http://freepages.genealogy.rootsweb.ancestry.com/ crossroads/help/lebreton/index.html 
Photo 9:

City of Ottawa. (2015). Map. Pimisi. Retrieved from:

http://www.ligneconfederationline.ca/the-build/pimisi/map/

\section{Chapter 5 Images:}

\section{Photo 10:}

DTAH. (2015). West Don Lands. Retrieved from:

http://dtah.com/project/west-don-lands-parks-and-open-space-plan/

\section{Photos 11 and 12:}

Urban Strategies. (2015). London Docklands. Retrieved from:

http://www.urbanstrategies.com/project/london-docklands/

\section{Photo 13:}

GAD. (2011). File:Oslo Opera She Lies.jpg. Wikimedia Commons. Retrieved from: http://commons.wikimedia.org/wiki/File:Oslo_Opera_She_Lies.jpg

\section{Photos 14, 15, and 16:}

EAD JV Inc. (2015). Edmonton Arena District. Retrieved from: http:/www.ead.ca/

\section{Photo 17 and 18:}

City of Ottawa. (2015e). What's at Lansdowne. Retrieved from:

http://ottawa.ca/2/en/residents/parks-and-recreation/recreation-facilities/lansdownepark/whats-at-lansdowne

\section{Chapter 6 Images:}

\section{Photo 19:}

City of Ottawa. (2015). Gallery. Pimisi. Retrieved from:

http://www.ligneconfederationline.ca/the-build/pimisi/gallery/

\section{All maps used data from Carleton University's MADGIC Library:}

City of Ottawa and National Capital Commission. (n.d). Ottawa 1:2000 Scale Topographic Maps. Ottawa, Canada: Carleton University. Retrieved from:

https://www.library.carleton.ca/find/gis/geospatial-data/ottawa-12000-scaletopographic-maps 